\title{
2 \\ Molecular Genetics of Vestibular Organ Development
}

\author{
Weise Chang, Laura Cole, Raquel Cantos, and Doris K. Wu
}

\section{Introduction}

Normal development of the vertebrate inner ear depends on signals emanating from multiple surrounding tissues, including the hindbrain, neural crest, mesenchyme, and notochord (for reviews, see Fritzsch et al. 1998; Torres and Giraldez 1998; Fekete 1999; Kiernan et al. 2002). Primarily through the analyses of mutant mice with spontaneous mutations or targeted deletions (knockouts), several genes involved in the patterning of the inner ear have been identified. Analyses of the phenotypes resulting from mutations within some of these genes, as well as analyses of their spatial and temporal expression patterns, indicate that they play specific, and sometimes multiple, roles in the patterning of the vestibular and auditory components of the inner ear (Table 2.1). Here, we summarize our current knowledge of the molecular mechanisms governing the development of the inner ear and the roles played by a variety of genes, focusing on the vestibular apparatuses of the chicken and mouse.

\section{Gross Development of the Vestibular Apparatus}

The membranous portion of the vertebrate inner ear originates from a thickening of the ectoderm adjacent to the hindbrain (Fig. 2.1). This thickened epithelium, known as the otic placode, invaginates to form the otic cup, which closes to form the otic vesicle/otocyst. A subpopulation of epithelial cells in the anteroventral lateral region of the otic cup and otic vesicle delaminate and coalesce to form the eighth (vestibulocochlear) ganglion. The otic vesicle proper undergoes a series of elaborate morphogenetic changes to give rise to an intricate, mature inner ear.

Figure 2.2 illustrates the gross development of the mouse inner ear from a late stage of otic vesicle formation through maturity, a period covering the complete development of the vestibular apparatus (Morsli et al. 1998). The vestibular component of the inner ear develops largely from the dorsal 
12 W. Chang et al.

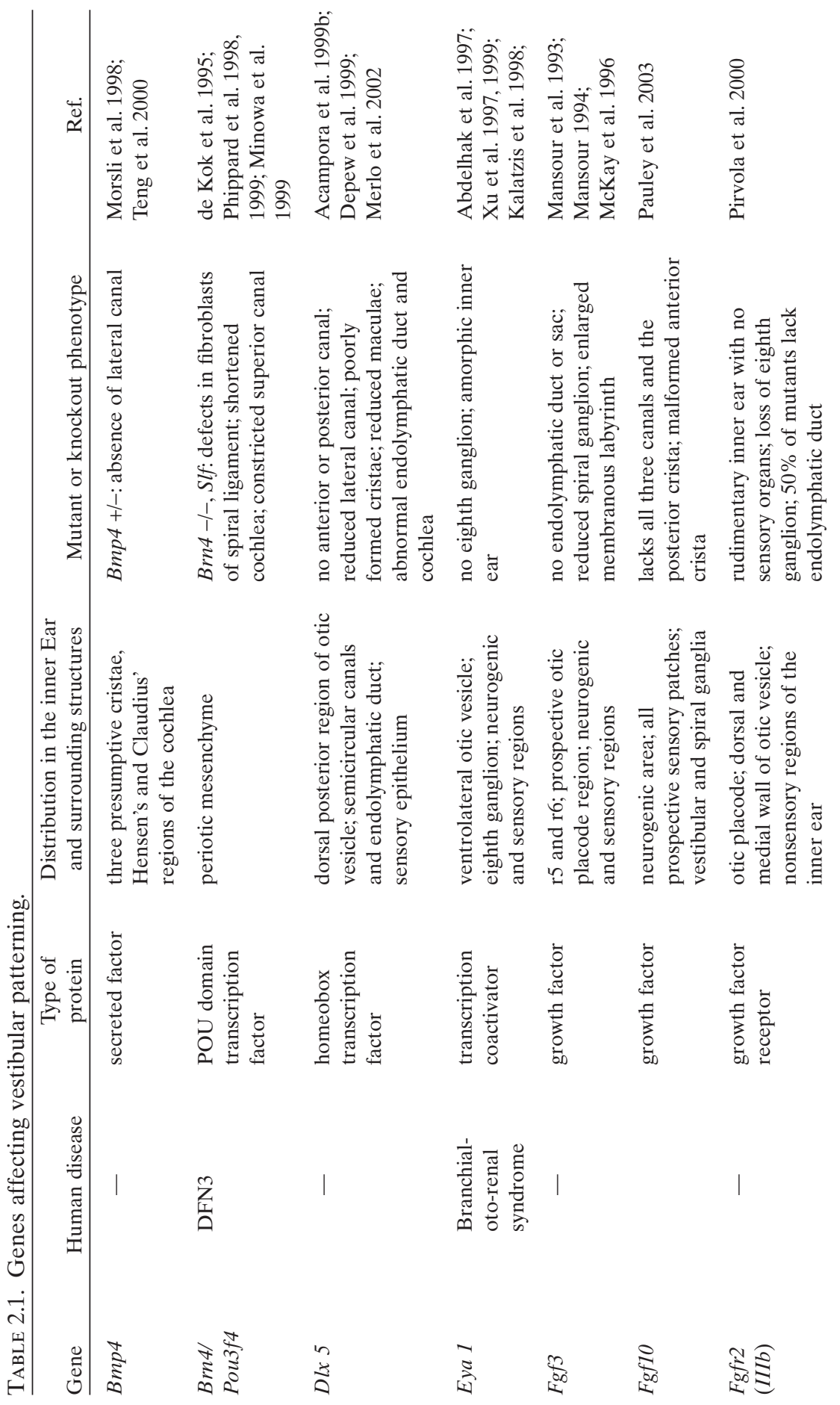



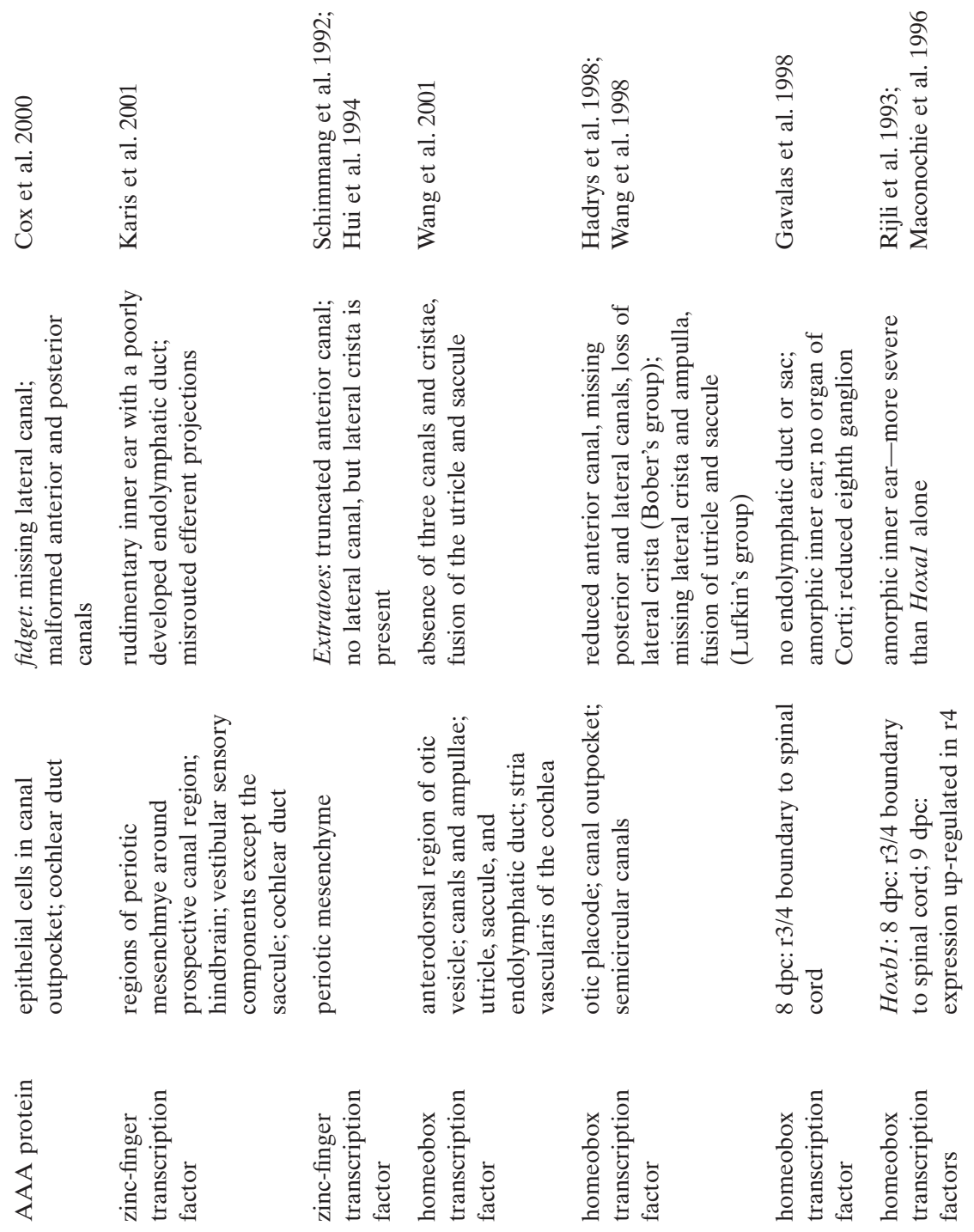

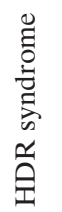

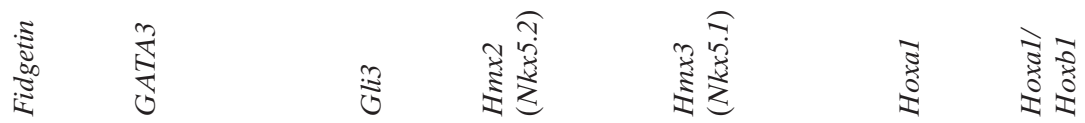


W. Chang et al.

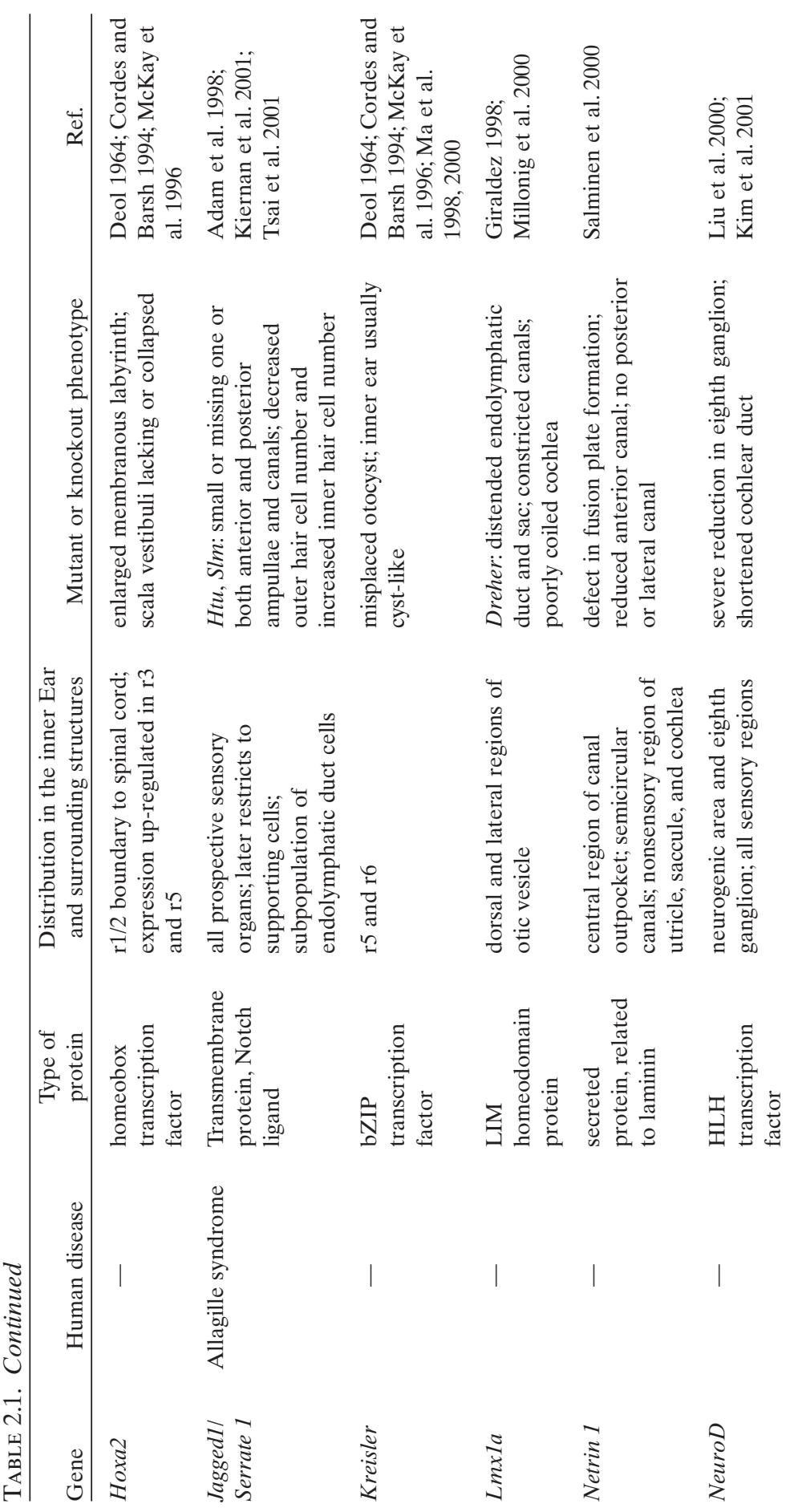




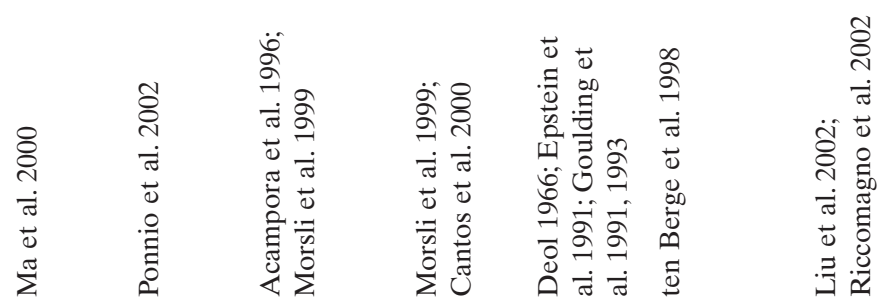

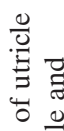

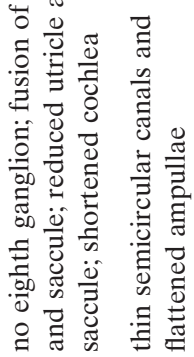

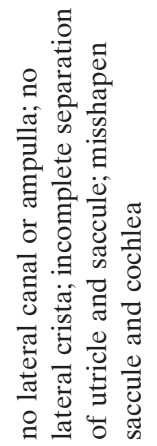

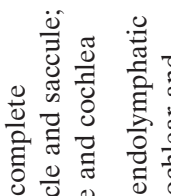

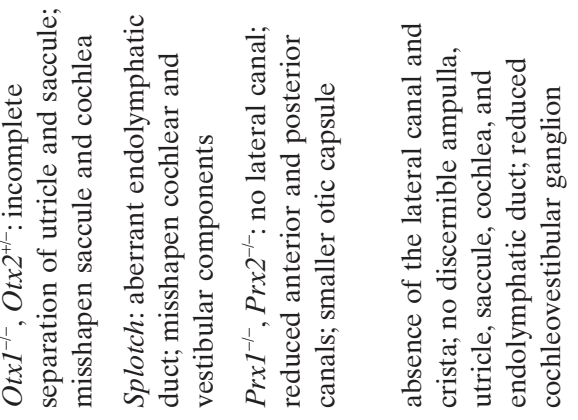
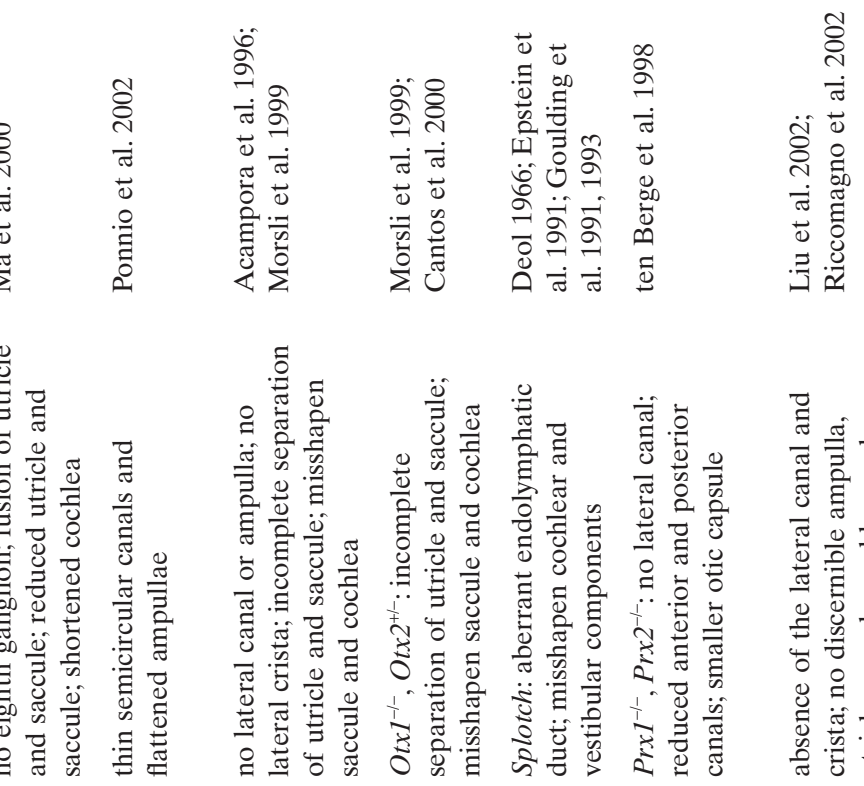

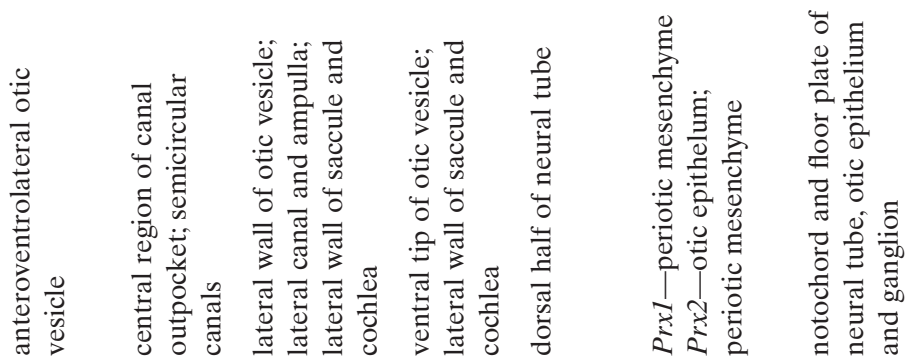

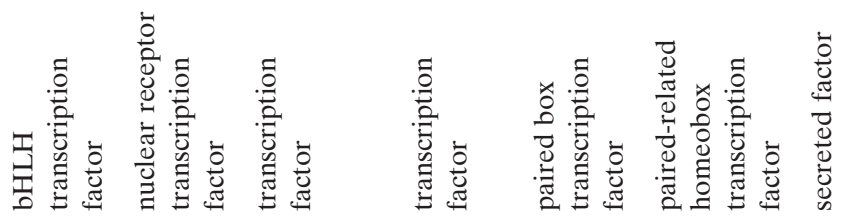

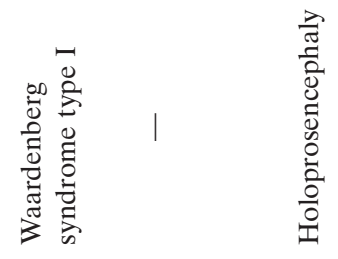

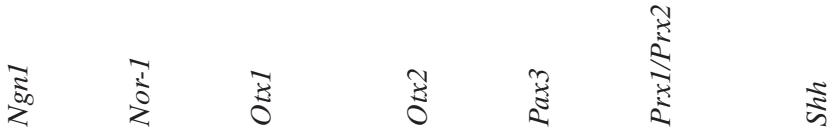


$\mathfrak{L}_{M}$
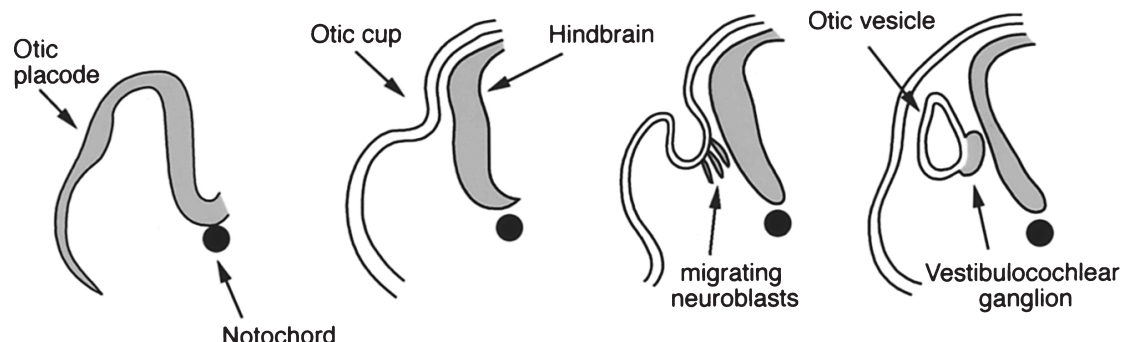

FIgURE 2.1. A schematic diagram summarizing the stages of inner ear development from an otic placode to an otic vesicle. These stages span approximately $8.5-9.5 \mathrm{dpc}$ (days postcoitium) in mice, and embryonic days 1.5-2.5 (Hamburger and Hamilton stages 9-17) in chickens. Orientations: D, dorsal; M, medial. (Adapted from Wu and Choo 2003.)
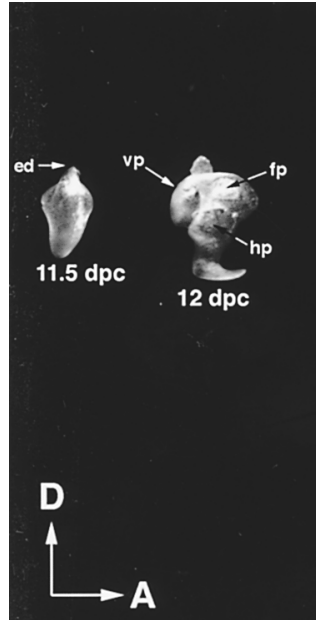
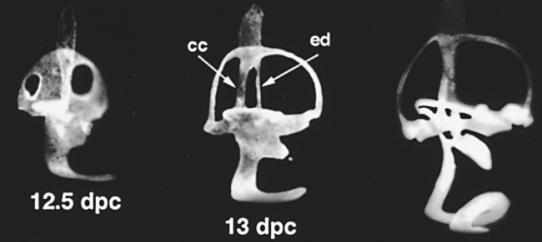

15 dpc

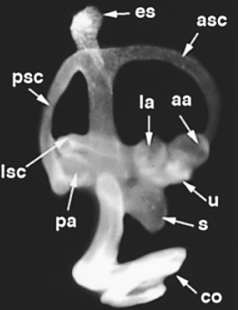

P1

FIGURE 2.2. Lateral views of paint-filled membranous labyrinths of mice from $11.5 \mathrm{dpc}$ to postnatal day 1 . Specimens were fixed in paraformaldehyde, dehydrated in ethanol, and cleared in methyl salicylate. The gross anatomy of the developing inner ears was revealed by microinjecting a $0.1 \%$ white latex paint solution in methyl salicylate to the lumen of the membranous labyrinths. Abbreviations: aa, anterior ampulla; asc, anterior semicircular canal; cc, common crus; co, cochlea; dpc, days postcoitium; ed, endolymphatic duct; es, endolymphatic sac; fp, fusion plate; hp, horizontal canal plate; la, lateral ampulla; lsc, lateral semicircular canal; pa, posterior ampulla; psc, posterior semicircular canal; s, saccule; $\mathrm{u}$, utricle; vp; vertical canal plate. Orientations: D, dorsal; A, anterior. Scale bar $=30 \mu \mathrm{m}$. 
region of the otic vesicle, and it consists of the utricle, saccule, and three semicircular canals (anterior, lateral, and posterior) and their associated ampullae. At one end of each semicircular canal is an enlarged structure known as the ampulla that contains a sensory organ, the crista ampullaris. Together, the three cristae sense angular acceleration. Two additional sensory organs, the maculae of the utricle and saccule, are located in their respective chambers. The macula of the utricle detects gravity, and the macula of the saccule detects linear acceleration. The total number of vestibular sensory organs varies among different vertebrate species. For example, there are seven vestibular sensory organs in the chicken (three cristae, two maculae, the lagena, and macula neglecta) and only five major ones in the mouse. The number varies even more among anamniotes (Wersäll and Bagger-Sjöbäck 1974). However, the five vestibular sensory organs in the mouse (three cristae and two maculae) are consistently found among all species of amniotes, including humans.

The anterior and posterior semicircular canals develop from the vertical canal plate, and the lateral semicircular canal develops from the horizontal plate (vp, hp in Fig. 2.2). Over time, the opposing epithelia in the central region of each presumptive canal merge to form a fusion plate (fp), which is eventually resorbed, leaving behind a tube-shaped canal. In mice, this process is completed by 13 days postcoitium (dpc). After the canals and ampullae are formed, they continue to increase in size at least until birth. During this same developmental period, the auditory component of the inner ear, the cochlea, develops from the ventral portion of the otocyst and assumes its characteristic coiled structure (Cantos et al. 2000). The development of the chicken inner ear closely parallels that of the mouse except that the cochlear duct in the chicken is a relatively straight tube rather than a coiled structure (Bissonnette and Fekete 1996).

Although not generally considered part of the vestibular apparatus, the endolymphatic duct is the first structure that forms on the medial side of the otic vesicle. Fate mapping studies of the rim of the chicken otic cup using lipophilic dye have shown that the endolymphatic duct derives from the dorsal rim of the otic cup. Three lineage-restricted boundaries appear to specify the position of the endolymphatic duct: anterior and posterior boundaries at the dorsal pole of the otic cup that bisect the endolymphatic duct into anterior and posterior halves, and a lateral boundary that defines the lateral edge of the duct. It has been proposed that signaling across compartment boundaries may play a role in duct specification (Brigande et al. 2000a, 2000b). Thus, failure in the formation of these boundaries would result in the absence or improper specification of the endolymphatic duct and may have other deleterious effects on inner ear development. Consistent with this hypothesis, malformed inner ears that lack an endolymphatic duct are often associated with other abnormalities of the inner ear (see below). As the endolymphatic duct and sac mature, they become essential 
for maintaining the fluid homeostasis of the endolymph that fills the membranous labyrinth. Abnormal fluid homeostasis also leads to functional deficits in vestibular and auditory systems (see below). Molecular mechanisms regulating the proper development and function of the vestibular apparatus involve signals that originate from several different tissues, including the hindbrain, periotic mesenchyme, and otic epithelium itself. In the following discussion, we address the roles played by each of these tissues, beginning with the hindbrain.

\section{Genes Expressed in the Hindbrain}

Experimental manipulations have established a critical role of the hindbrain in the development of the inner ear (for reviews, see Fritzsch et al. 1998; Torres and Giraldez 1998; Fekete 1999; Anagnostopoulos 2002). Based on analyses of mutant and knockout mice, several genes expressed in the hindbrain have been shown to be required for normal development of the inner ear, including the vestibular system. HoxA1, HoxA2, Kreisler, and Raldh2 are all expressed in the developing hindbrain. Loss of function of these gene products affects the development of the hindbrain-in particular, rhombomeres 4,5, and 6, regions that are closest to the developing inner ear (for a review, see Kiernan et al. 2002). Inner ears of all of these mutant mice often fail to form endolymphatic ducts and remain cystlike, suggesting that rhombomeric regions 4 to 6 of the hindbrain, in particular rhombomere 5, are required for the formation of vestibular and auditory structures.

The expression of the Fibroblast growth factor 3 (Fgf3) in rhombomeres 5 and 6 is also thought to be important for inner ear development. In both Kreisler and HoxA1 mutant mice, Fgf3 expression in the hindbrain is downregulated (Carpenter et al. 1993; Mark et al. 1993; McKay et al. 1996). This down-regulation of $F g f 3$ expression has been proposed to contribute to the Kreisler and HoxA1 phenotypes. This hypothesis is supported by the fact that inner ears of $F g f 3$ knockout mice also lack endolymphatic ducts. Furthermore, morphogeneses of the mutant inner ears are often incomplete, and the spiral ganglia are reduced in size (Mansour et al. 1993; Mansour 1994; McKay et al. 1996). It is interesting that the knockout of one of the FGF3 receptors, $F g f r-2(I I I b)$, that is expressed in the otic epithelium results in severe dysmorphogenesis of the inner ear, including the absence of the endolymphatic duct and sac (Pirvola et al. 2000). Part of the phenotype observed in Fgfr-2 (IIIb) knockout mice might be attributable to the inability of the otic epithelium to respond to FGF3 signals produced in the hindbrain (Pirvola et al. 2000).

Analysis of the role of hindbrain-derived FGF3 in the development of vestibular structures has been compounded by the observation that $F g f 3$ is expressed not only in the hindbrain but also within the inner ear itself. Early 
in development, $F g f 3$ is expressed in the head ectoderm, including the otic placode region. It is also expressed in the presumptive neurogenic region of the otocyst as well as in individual sensory organs of the inner ear before birth (Wilkinson et al. 1989; Mansour 1994; McKay et al. 1996; Pirvola et al. 2000). Whereas the endolymphatic duct phenotype is thought to be mediated by hindbrain-derived FGF3, Fgf3 expression in the neurogenic region is thought to be important for the proper formation of the spiral ganglion that is reduced in the Fgf3 knockout mice (Mansour et al. 1993; Mansour 1994; McKay et al. 1996). Although Fgf3 is presumably expressed in the sensory regions, no obvious sensory phenotypes were associated with the Fgf3 knockout (Mansour et al. 1993; Mansour 1994). Because Fgf10 is expressed in the sensory regions as well, there could be overlapping functions among Fgfs in these regions (Pirvola et al. 2000). Therefore, in the case of genes such as $F g f 3$ that have a dynamic spatial and temporal expression pattern in the hindbrain as well as in the otic epithelium, it is important to decipher its specific function in each expression domain.

A more recently identified dominant mouse mutant, Wheels, may also serve as a model for studying effects of the hindbrain on inner ear development (Alavizadeh et al.2001). Wheels homozygotes are embryonic lethal and have an abnormal hindbrain with an extended rhombomere 4 that could affect inner ear development. Although the hindbrain segmentation in heterozygotes appears normal, these mice have a truncated lateral canal and small or absent posterior canal, suggesting that the otic epithelium itself and/or tissues other than the hindbrain are involved. Identification of the mutated gene and determination of its normal expression pattern will help to discern the role of this gene in inner ear patterning.

All of the hindbrain genes that have been discussed thus far most likely function to ensure correct positioning of the developing inner ear along the anterior/posterior axis of the body. The hindbrain could also function to specify the dorsal/ventral axis of the inner ear. Mutations in genes such as (Sonic Hedgehog) (Shh), Pax3, and Lmx1 that are known to perturb the dorsal/ventral patterning of the neural tube also affect inner ear development. Because these genes may be expressed in both the inner ear and hindbrain, it is often difficult to determine the relative contributions played by signals produced by the hindbrain or inner ear. Nonetheless, due to the severe inner ear phenotypes observed in mice with mutant alleles of these neural tube specifying genes, it is clear that these genes are also essential for proper inner ear development.

Inner ears of Shh knockout mice have no discernible ventral structures, including the utricle, saccule, and cochlea. The delamination of neuroblasts from the anteroventral region of the otic cup or otocyst is also affected in these mutant ears. Even though it has been postulated that $\mathrm{SHH}$ released from the ventral midline patterns the inner ear (Riccomagno et al. 2002), the presence of low levels of Shh within the otic epithelium has been reported (Liu et al. 2002). Although the source of SHH for patterning the 
inner ear remains an open question, it is clear that the otic epithelium responds directly to $\mathrm{SHH}$ as indicated by the presence of Patched (receptor for $S h h$ ) and Glil (a downstream target of Shh) mRNA transcripts within the epithelium (Liu et al. 2002; Riccomagno et al. 2002).

Furthermore, two additional mouse models, Splotch and Dreher, have disrupted neural tubes along the dorsal/ventral axis as well as malformed inner ears. Splotch mutants have an open neural tube and inner ear defects that include vestibular and auditory components (Deol 1966; Epstein et al. 1991; Goulding et al. 1991; Rinkwitz et al. 2001). Consistent with the phenotype, Pax3, which is mutated in Splotch, is expressed in the dorsal one-third of the neural tube. A detailed study of Pax3 expression in the inner ear has not been reported, although Pax3 does not appear to be expressed during early stages of inner ear development (Goulding et al. 1991).

In Dreher, the roof plate of the neural tube fails to form, and defects in the inner ear involve both vestibular and cochlear components (Deol 1983). In addition, the endolymphatic duct and sac are greatly distended. The gene responsible for this mutant is Lmxla, a LIM homeodomain transcription factor (Manzanares et al. 2000; Millonig et al. 2000). The expression of Lmx1 or Lmxla has been described in both chickens and mice, respectively (Giraldez 1998; Failli et al. 2002). This gene is expressed in the roof plate of the neural tube as well as the dorsal and lateral regions of the otocyst. Its expression domain in the otic placode is altered as a result of neural tube ablation, suggesting that the otic expression of this gene, at least in the chicken, is regulated by hindbrain signals (Giraldez 1998).

\section{Genes Expressed in the Mesenchyme}

In addition to signals produced by the hindbrain, the development of the inner ear is also influenced by mesenchyme-derived signals. In fact, the epithelium of the otic placode/otocyst and the surrounding periotic mesenchyme are thought to exert reciprocal influences on each other during normal inner ear development. Results from explant cultures show that morphogenesis of the inner ear does not proceed when the majority of the periotic mesenchyme is removed (Van de Water et al. 1980). Similarly, chondrogenesis in vitro requires growth factors that are thought to be released by the otic epithelia such as bone morphogenetic proteins (BMP), transforming growth factor- $\beta$ (TGF- $\beta$ ), and FGF2 (Frenz et al. 1992, 1994, 1996). Recently, ectopic expression studies in the chicken using avian retroviruses encoding dominant-negative or a constitutive active form of bone morphogenetic protein receptor IB (BMPRIB) show that BMPs are indeed important for otic chondrogenesis in vivo. BMPs for some regions of the otic capsule, such as areas around the canals, are thought to emanate from the otic epithelium (Chang et al. 2002). 
Analyses of genetically altered mice indicate that three transcription factors, Prx1, Prx2, and Brn4, regulate genes important for mesenchymal-epithelial signaling. Prx 1 and Prx 2 are paired-related homeobox genes. $\operatorname{Pr} x 1$ is expressed in the periotic mesenchyme, and Prx 2 is expressed in the otic epithelium as well as the periotic mesenchyme. A knockout of Prx1 results in a reduction in the size of the otic capsule, whereas a knockout of $\operatorname{Prx} 2$ has no apparent phenotype in the inner ear (ten Berge et al. 1998). $\operatorname{Prx} 1$ and Prx2 share redundant functions in other tissues. Therefore, it is not surprising that the double knockout of both $\operatorname{Prx} 1$ and $\operatorname{Pr} x 2$ results in a more severe inner ear phenotype. In addition to the reduction in the size of the otic capsule observed in the knockout of Prx1, in the double knockout, the lateral semicircular canal does not form, and there is a reduction in the size of both the anterior and posterior canals (ten Berge et al. 1998). These results suggest that the coexpression of Prx1 and Prx2 in the periotic mesenchyme is important for mediating mesenchymal-epithelial signaling in the vestibular apparatus.

Brn4 (Pou3f4), a transcription factor belonging to the POU-domain gene family, is expressed in the periotic mesenchyme (Phippard et al. 1998). Knockout mice of Brn4 are deaf, and vestibular phenotypes such as head bobbing have been reported in one of the two knockout lines (Minowa et al. 1999; Phippard et al. 1999). The primary cell type affected in the Brn4 knockout mice appears to be the fibrocytes of the spiral ligament that have been postulated to be important in maintaining the endocochlear potential (Minowa et al. 1999; Phippard et al. 1999). Interestingly, in one of the Brn4 knockout lines, patterning defects in the cochlea were reported (Phippard et al. 1999). The number of cochlear turns in this mutant line is often affected, and the anterior semicircular canal is constricted. The constriction of the anterior semicircular canal is thought to be the cause of the vestibular deficits (Phippard et al. 1999). The reason for the phenotypic variation observed between the two knockout lines is not clear because the genetargeted region and the genetic background of the mutant mice are similar. However, sex-linked fidget (slf) mice have an inversion on the $\mathrm{X}$ chromosome that eliminates expression of Brn4 in the developing inner ear but not the neural tube. These mice, like one of the Brn4 knockout lines, display both cochlear and vestibular deficits (Phippard et al. 2000). These results provide the first evidence that a gene, expressed primarily in the periotic mesenchyme, mediates otic epithelial morphogenesis. Identifying possible upstream signaling molecules and downstream targets for this transcriptional factor, whether they are epithelium- or mesenchyme-derived, will be important. It is interesting that, in the Shh mutants, both Brn 4 and TbxI are down-regulated in the otic mesenchyme (Riccomagno et al. 2002). The otic capsule is reduced in $S h h$ mutants, indicating that other molecular pathways that mediate otic chondrogenesis are not perturbed by the loss of Shh. However, the cochlear defects observed in Brn4 knockout mice suggest that 
Shh could mediate its effects on inner ear patterning through activating Brn4 as well as Tbx1 in the mesenchyme.

\section{Genes Expressed within the Otic Epithelium}

It is not surprising that genes expressed in the otic epithelium itself are important for the development of the vestibular apparatus (Table 2.1). Some of these genes, when knocked out, result in a rudimentary inner ear with poorly developed vestibular as well as cochlear components. These inner ears often lack endolymphatic ducts as well as the vestibular and spiral ganglia. Fgfr-2 (IIIb), GATA-3, and Eyes absent (Eyal) are good examples of genes in this category (Xu et al. 1999; Pirvola et al. 2000; Karis et al. 2001). All three genes are activated early in development and are broadly expressed in the inner ear, particularly during the otic cup and otocyst stages (Xu et al. 1997; Pirvola et al. 2000; Karis et al. 2001). As described above, the severe phenotype of the Fgfr-2 (IIIb) knockout could be a result of its inability to respond to growth factor signals produced by the hindbrain as well as by sensory regions of the otic epithelium.

GATA-3 is a member of a zinc-finger transcription factor family that recognizes a specific GATA consensus sequence in promoter regions. Genes in this family are important for differentiation of multiple tissues during embryogenesis, including the brain and hematopoietic system (Simon 1995). In the otocyst, GATA-3 is broadly expressed within the otic epithelium, and, as differentiation progresses, $G A T A-3$ is expressed in all of the vestibular sensory organs except the saccule. The vestibular ganglion is also devoid of GATA-3 expression (Karis et al. 2001). Within the auditory structures of the inner ear, both the cochlear duct and spiral ganglion are positive for GATA-3. Interestingly, the repression of GATA-3 expression is correlated spatially and temporally with hair cell differentiation, which proceeds in a gradient from the base to the apical region of the cochlea (Rivolta and Holley 1998). GATA-3 null mutants die between 11 and $12 \mathrm{dpc}$ and have rudimentary inner ears (Karis et al. 2001). Correlating phenotypes with expression domains will be a challenge for this gene because GATA-3 is expressed not only in the inner ear but also in the hindbrain and periotic mesenchyme (Nardelli et al. 1999).

Eya-1 is a homolog of the Drosophila eyes absent gene. In the Drosophila eye imaginal disk, eya functions as a transcription coactivator that interacts with other transcription factors but does not bind DNA directly (Chen et al. 1997; Pignoni et al. 1997). Mutations in this gene in humans cause branchiootorenal syndrome, which is associated with defects in the kidney as well as the external, middle, and inner ear (Abdelhak et al. 1997). Expression of Eya-1 in the inner ear is extensive at the otocyst stage, and Eya-1 null mutants have rudimentary inner ears that lack the eighth ganglion $(\mathrm{Xu}$ 
et al. 1999). A hypomorphic allele of Eya-1 has also been identified. In this case, the vestibular portion of the inner ear appears intact but the cochlear duct is truncated, suggesting that Eya-1 is particularly essential for cochlear development (Johnson et al. 1999).

Because knockouts of genes such as Fgfr-2 (IIIb), GATA-3, and Eya-1 have such deleterious effects on inner ear development in general, it is often difficult to discern their specific effects on individual inner ear components. On the other hand, knockouts of transcription factor genes such as Otx1, $H m x 2$ and Hmx3 (Nkx5.2 and Nkx5.1), and Dlx5 affect the development of specific components of the inner ear (Hadrys et al. 1998; Wang et al.1998; Acampora et al. 1999b; Depew et al. 1999). More detailed descriptions of the functions of these and other genes in the development of individual vestibular components are given below.

\subsection{Development of the Sensory Organs}

The origin and the lineage relationships among the vestibular sensory organs within the inner ear are not known. However, early in inner ear development, prior to any discernible histological differentiation, the presumptive cristae of the semicircular canals can be molecularly distinguished from the presumptive maculae of the utricle and saccule. Based on the different morphologies of the cristae and maculae at maturity, it is not surprising that multiple genes are differentially expressed in these sensory organs during the course of their development. Therefore, it is important to identify those essential for the specification and differentiation of each type of sensory organ.

Thus far, genes that are expressed in the sensory tissues can be divided into two groups: those that do and do not act in the Notch-signaling pathway (Fig. 2.3). The Notch signaling pathway is used in a variety of tissues to generate cell type diversity during development (for reviews, see Artavanis-Tsakonas and Simpson 1991; Artavanis-Tsakonas et al. 1999). Originally delineated by studies of neurogenesis in invertebrate systems, the Notch signaling pathway relies on local cell interactions to control the differential specification of otherwise equivalent cells. For example, in the case of invertebrate neurogenesis, Notch signaling mediates the decision of whether ectodermal cells become neuroblasts or epidermal cells. Several molecules acting in the Notch pathway have been identified and include the Notch receptors and several membrane-associated Notch ligands such as Delta and Serrate. During fruit fly (Drosophila) central nervous system development, clusters of neural precursor cells develop within the ectodermal epithelium via the expression of proneural genes, encoded by the achaete-scute complex. Then, one cell from each cluster will become committed to the neural fate, and others will cease to express achaete-scute genes and switch to the epidermal fate. This process is mediated by the Notch pathway. Notch ligands displayed on the committed neural cell acti- 


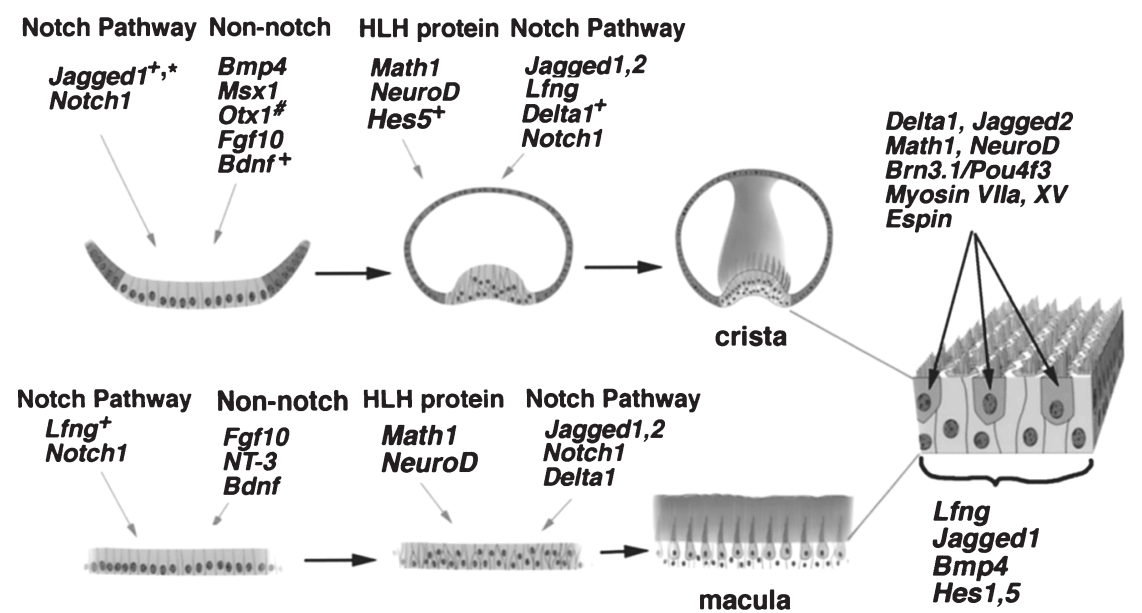

Figure 2.3. A schematic diagram outlining genes expressed in different stages of the crista and macula development. For simplification, sensory organ development is divided into three stages corresponding to $9.5-11,12-14$, and $15-18 \mathrm{dpc}$ in mice. Readers should refer to cited references for specific timing of individual gene activation. $(+)$ represents initiation of gene expression in the indicated prospective sensory organ before others. (\#) represents expression only in the lateral crista and not the anterior or posterior cristae. $(*)$ represents expression data from chickens. Hes 1 is expressed in supporting cells of the rat utricle at $17.5 \mathrm{dpc}$, and it is not clear whether it is expressed in other vestibular sensory tissues as well. In mice, Bmp 4 is only expressed in supporting cells of cristae and not in maculae.

vate Notch receptors in its neighboring cells and thus activate an alternate developmental pathway, an epidermal fate in this case.

The development of the sensory patches in the vertebrate inner ear has been compared with that of the mechanoreceptor organs in fruit flies (Drosophila) (Adam et al. 1998; Eddison et al. 2000; Fritzsch et al. 2000; Caldwell and Eberl 2002). Based on expression studies of Notch signaling molecules, it has been proposed that the expression of Notch ligands, Delta and Jagged/Serrate, on the surface of presumptive sensory hair cells activated Notch receptors present on neighboring cells (Adam et al. 1998; Lewis et al. 1998). This activation of Notch receptors in the neighboring cells induced them to develop into supporting cells. Consistent with this model, mutation of genes in the Notch signaling pathway usually results in changes in the number of hair cells and presumably supporting cells in the sensory organs. For example, knockout of a Notch ligand, Jagged2, results in an increase in the number of inner and outer hair cells in the cochlea (Lanford et al. 1999). In the zebrafish (Brachydanio rerio) mind bomb mutant, in which the Delta-Notch signaling pathway is thought to be affected, the inner ear contains only hair cells and no supporting cells 
(Haddon et al. 1998). In addition, treatment of rat cochlear cultures with antisense oligonucleotides of Jagged1 and Notch1 result in supernumerary hair cells (Zine et al. 2000).

\subsubsection{Development of the Crista Ampullaris}

\subsubsection{Notch Signaling Pathway}

In the mouse, both Notch1 and Serrate1/Jagged1 are expressed in all presumptive sensory organs of the inner ear. During later stages of development, the expression domains of both of these genes are restricted to nonsensory cells within each sensory patch (Lewis et al. 1998; Morrison et al. 1999; Shailam et al. 1999). Recent data suggest that the function of the Notch signaling pathway is not restricted to hair cell/supporting cell determination in the inner ear but is also required for the patterning of the ampulla and canal. Two mouse mutants, Headturner and Slalom, with missense mutations in the Notch ligand, Jagged1, have recently been characterized. Homozygotes of both mutants die at early embryonic stages due to vasculature defects, and heterozygotes have an aberrant number of hair cells in the cochlea (Kiernan et al.2001; Tsai et al.2001). Interestingly, Headturner and Slalom are missing one or both of the anterior and posterior ampullae. The ampulla phenotype is accompanied by truncation of its corresponding canal. Despite the phenotype in the anterior and posterior canals, the lateral canal and ampulla appear to be intact in these mutants. It is not clear why the anterior and posterior ampullae are preferentially affected because Jagged1 is expressed in all prospective sensory organs (Morrison et al. 1999). Coincidentally, in the chicken, Jagged1/Serrate1 is expressed in the presumptive anterior and posterior cristae earlier than in other sensory organs (Myat et al. 1996; Cole et al. 2000). Therefore, if the expression pattern of Jagged1 in mice is similar to that of the chicken, the patterning phenotype observed in Slalom and Headturner might be due to the requirement of Jagged1 function prior to hair cell/supporting cell determination.

Some genes in the Notch signaling pathway, such as Jagged2 and Hes5, however, are activated slightly later during sensory organ development and are correlated with the period of hair cell and supporting cell commitment (Fig. 2.3). Jagged2 is expressed in presumptive hair cells of each sensory patch (Lanford et al. 1999; Shailam et al. 1999). Hes5, a basic-helix-loophelix (bHLH) transcription factor, is a homolog of the Drosophila hairy and enhancer-of-split. It is one of the downstream genes activated by Notch. Hes 5 is preferentially expressed in the presumptive cristae at $12.5 \mathrm{dpc}$ and is later expressed in supporting cells of the cristae and striolar region of the utricle (Shailam et al. 1999; Zheng et al. 2000). In other systems, members of the bHLH family of transcription factors have been shown to be both upstream mediators and downstream targets of the Notch signaling pathway (for a review, see Anderson and Jan 1997). In addition to 
Hes5, other examples of downstream targets of the Notch signaling pathway that are expressed in the inner ear include Hes1, Hes6, Hey1, and Hey2 (Leimeister et al. 1999; Pissarra et al. 2000; Zheng et al. 2000). Detailed expression studies and the consequences of loss of some of these encoded proteins during inner ear development have not been reported. However, Math1, a bHLH transcription factor, might be an upstream mediator of the Notch pathway in the inner ear. Math1 is a homolog of the fruit fly (Drosophila) proneural gene atonal, which is important for the formation of chordotonal organs (mechanoreceptor organ) in flies. In mice, Math1 -/- inner ears have no sensory hair cells even though the gross anatomy of the sensory organs appears normal (Bermingham et al. 1999). In addition, ectopic expression of Math1 in rat cochlear cultures resulted in an ectopic appearance of sensory hair cells in nonsensory regions (Zheng and Gao 2000). The onset of Math1 expression in individual sensory organs appears to precede that of Jagged2, consistent with its postulated role as a proneural gene (Shailam et al. 1999; Liu et al. 2000). However, more recent studies suggest that Math1 functions in hair cell determination rather than specification of the sensory primordium (Chen et al. 2002). The important role of Math1 in sensory development will undoubtedly be revealed with further experiments.

NeuroD belongs to a subfamily of bHLH proteins that are widely expressed in the nervous system of vertebrates and are potent neuronal differentiation factors (Lee et al. 1995). NeuroD is expressed in the presumptive cristae, but the cristae of NeuroD knockout mice appeared normal, even though the number of sensory hair cells in the cochlea is aberrant (Liu et al. 2000; Kim et al. 2001). In addition, NeuroD is important for the development of the eighth ganglion (see below).

\subsubsection{Non-Notch Pathway}

Examples of genes that are expressed in the presumptive cristae but are not components of the Notch-signaling pathway include Bmp4 and Msx1 (Fig. 2.3). Bmp 4 belongs to the TGF- $\beta$ gene family and plays an important role in the development of multiple tissues (for a review, see Hogan 1996). In the mouse inner ear, $B m p 4$ is expressed at the rim of the invaginating otic cup (Morsli et al.1998). After the otic cup closes to form the otic vesicle, Bmp4 expression is restricted to two domains, an anterior streak and a posterior focus (as, pf in Fig. 2.4A,B; Morsli et al. 1998). The posterior focus corresponds to the position of the future posterior crista. The posterior expression domain later splits to form the dorsal posterior crista and a ventral streak that corresponds to Hensen's and Claudius' regions of the cochlea in mice (pc and lco in Fig. 2.5A). The anterior streak also splits to form the anterior and lateral cristae at a later time of development (Figs. 2.4A, 2.5A; Morsli et al. 1998). The early expression of Bmp4 in the otic cup and otocyst stages is conserved in the chicken, frog, and zebrafish, but the 

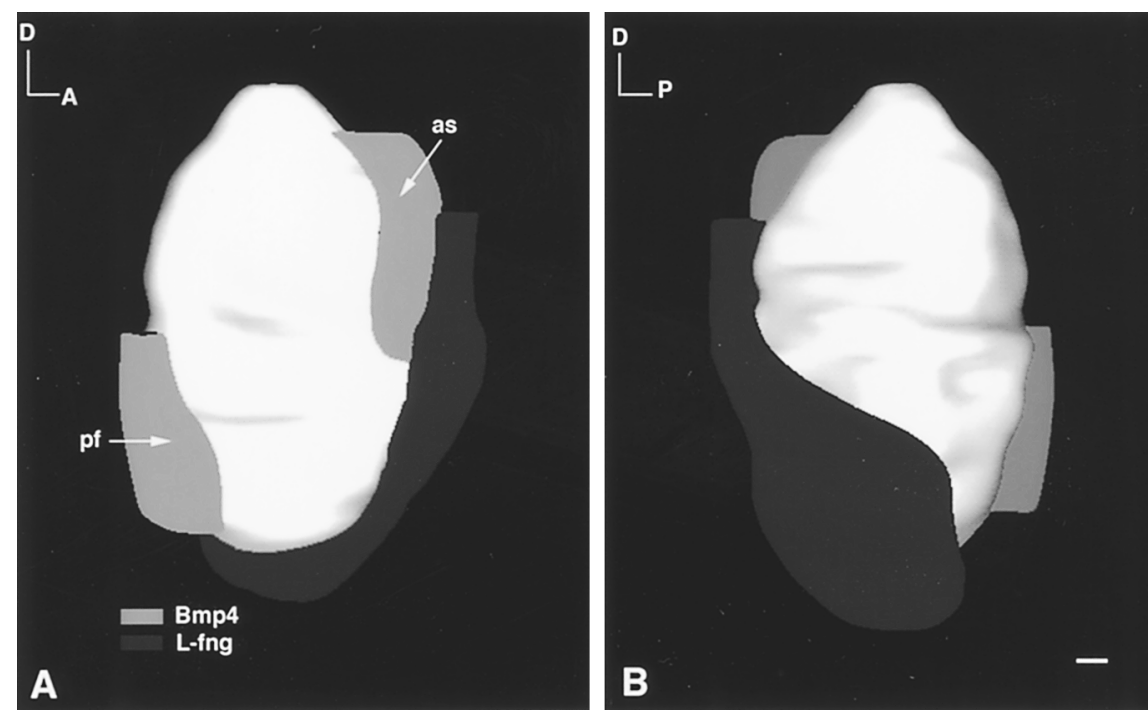

Figure 2.4. A three-dimensional reconstruction of Bmp4 and L-fng expressions in the mouse inner ear at $10.5 \mathrm{dpc}$. The lateral (A) and medial (B) views of the right inner ear are shown. The emerging endolymphatic duct on the medial side at this stage is not drawn. Bmp 4 positive regions are displayed in light gray and the $L$-fng positive area in dark gray. Alternate $12 \mu \mathrm{m}$ serial sections were probed for $B m p 4$ or L-fng mRNA and reconstructed using ROSS software (Biocomputation Center, Ames Research Center, NASA). Data for the reconstruction were obtained from Morsli et al. (1998). The anterior streak (as) of the Bmp4 hybridization signal later splits to form the anterior and lateral cristae (see Fig. 2.5A). The posterior focus (pf) encompasses the presumptive posterior crista. $L$-fng is broadly expressed at this stage with an expression domain that spans from the anterolateral region to the ventromedial region of the otocyst. $L$ - $f n g$ and $B m p 4$ expression domains are largely nonoverlapping. Orientation: D, dorsal; A, anterior; P, posterior. Scale bar $=30 \mu \mathrm{m}$.

role of Bmp4 in formation of the crista or other parts of the inner ear is not clear because Bmp4 null mice die before sufficient inner ear development (Hemmati-Brivanlou and Thomsen 1995; Mowbray et al. 2001; Wu and Oh 1996). However, some Bmp4 heterozygotes have a malformed lateral canal, indicating that BMP4 is essential for proper inner ear development (Teng et al. 2000). Because the receptors for $B m p 4$ are ubiquitously expressed in the otic epithelium and adjacent mesenchyme, Bmp4 could function both autonomously within the presumptive cristae and through effects on the adjacent nonsensory otic epithelium and periotic mesenchyme (Dewulf et al. 1995).

In the chicken, the early expression of Brain-derived nerve growth factor $(B d n f)$ has an expression pattern similar to that of Bmp4 (Hallbook et al. 

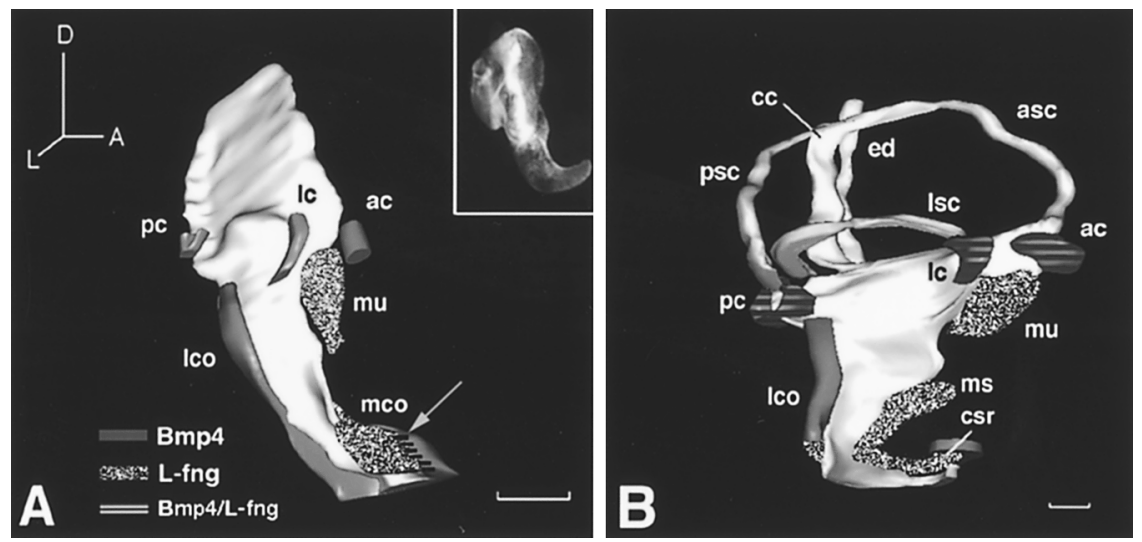

FIGURE 2.5. A three-dimensional reconstruction of $B m p 4$ and $L-f n g$ expression domains in the mouse inner ear at $12(\mathbf{A})$ and $13(\mathbf{B})$ dpc. Bmp4-positive areas are in light gray, and $L$-fng-positive areas are spotted. The arrow in A is pointing to black stripes that represent a region of Bmp 4 and $L-f n g$ coexpression in the distal tip of the growing cochlea. The insert in $\mathrm{A}$ is a $12 \mathrm{dpc}$ paint-filled inner ear shown in a view similar to the reconstructed image. By $13 \mathrm{dpc}(\mathrm{B})$, the cristae are positive for both Bmp4 and L-fng, highlighted in light and dark gray stripes. Data analysis and three-dimensional reconstructions were carried out as described in the legend to Figure 2.4. Abbreviations: ac, anterior crista; asc, anterior semicircular canal; cc, common crus; csr, cochlear sensory region; ed, endolymphatic duct; lc, lateral crista; lco, lateral cochlear hybridization signal; lsc, lateral semicircular canal; mco, medial cochlear hybridization signal; ms, macula sacculi; mu, macula utriculi; pc, posterior crista; psc, posterior semicircular canal. Orientation: A, anterior; D, dorsal; L, lateral. Scale bar $=100 \mu \mathrm{m}$. (Adapted from Morsli et al. 1998.)

1993). In mice, the early $B d n f$ expression pattern is also thought to overlap with that of Bmp4 (Fritzsch et al.1999). BDNF is required for proper innervation of the cristae by the vestibular ganglion (Fritzsch et al. 1999). Later in development, $B d n f$ is also expressed in the maculae.

Msx1 and Msx2 are orthologs of the Drosophila msh (muscle segment homeobox) gene and are important for mediating epithelial-mesenchymal interactions in several tissues during embryogenesis (Satokata and Maas 1994; Chen et al. 1996). The role of Msx1 in crista formation is not clear, but it is expressed in the presumptive cristae and not the maculae (Dewulf et al. 1995; Wu and Oh 1996; Alavizadeh et al. 2001). Msx1 knockout mice have no apparent phenotype in the inner ear (Satokata and Maas 1994). However, Msx1 may share redundant functions with Msx2. Inner ear analyses of mice with double knockouts of Msx1 and Msx2 have not been reported.

Fgf10 is expressed in the vestibulocochlear ganglion as well as each of the prospective sensory organs (Pirvola et al. 2000). Knockout of Fgf10 
results in absence of all three semicircular canals and the posterior crista. The anterior crista is malformed and misaligned relative to the utricle (Pauley et al. 2003).

\subsubsection{Genes Expressed in Specific Cristae}

The anterior and posterior cristae are anatomically indistinguishable from each other except for their positions within the inner ear, whereas the lateral crista is different in appearance and resembles half of an anterior or posterior crista (Landolt et al. 1975). Furthermore, the lateral canal and ampulla are the last among the three canals and ampullae to have arisen during vertebrate evolution and are absent in Agnatha (jawless vertebrates; for a review, see Wersäll and Bagger-Sjöbäck 1974). So far, no genes have been demonstrated to be exclusively expressed in either anterior or posterior cristae even though some genetic mutations differentially affect the two cristae (see below).

On the other hand, Otxl is expressed in the presumptive lateral crista and canal but not in the anterior or posterior cristae or their canals (Morsli et al. 1999). Otx1 and Otx2 are both vertebrate orthologs of Drosophila orthodenticle, which is important for sense organ and head development (Acampora et al. 1995; Hirth et al. 1995; Royet and Finkelstein 1995; Acampora et al. 1996; Ang et al. 1996). In Otx1 knockout mice, the lateral crista and canal fail to develop (Acampora et al. 1996; Morsli et al. 1999). However, Bmp4 expression in the Otx1 mutant inner ears is normal at the early otic vesicle stage, suggesting that the specification of the lateral crista may be normal initially and that Otx1 may be important for the subsequent differentiation of the sensory organ (Morsli et al. 1999). More recently, an ectopic sensory patch located on the medial side of the mutant inner ear by the endolymphatic duct was reported in Otx1 mutant inner ears (Fritzsch et al. 2001). It is not clear whether this sensory patch is a mispositioned lateral crista or the result of an aberrant segregation of sensory patches. Nevertheless, the function of $O t x 1$ in lateral canal and ampulla formation is indispensable and not compensated by replacing a human Otx2 cDNA in the disrupted Otx1 locus despite the sequence homology between the two genes and the ability of human Otx2 to rescue the brain phenotype observed in Otx1 mutant mice (Acampora et al.1999a; Morsli et al. 1999).

\subsubsection{Development of the Maculae}

\subsubsection{Notch Signaling Pathway}

The positions of the two presumptive maculae are marked by the expression of Lunatic fringe ( $L$-fng). L-fng is an ortholog of the Drosophila fringe gene that acts in the Notch signaling pathway to establish boundaries during 
the development of both flies and vertebrates (Laufer et al. 1997; Panin et al.1997; Evrard et al. 1998; Papayannopoulos et al. 1998; Zhang and Gridley 1998). Recent data show that Fringe mediates its effect by forming complexes with Notch receptors and modulating their ligand preferences (Hicks et al. 2000; Ju et al. 2000). In the inner ear, $L$-fng is expressed in an anterolateral domain of the otic cup that later expands medially (Morsli et al.1998; Fig. 2.4A,B). The $L-f n g$ positive domain encompasses three presumptive sensory organs: the maculae of the utricle and saccule and the sensory tissue of the cochlea. In addition, based on its location, the lateral region of the $L$-fng positive area most likely encompasses the cells that are delaminating at this stage to form the eighth cranial ganglion even though $L$-fng transcripts were not detected in the migrating neuroblasts (Morsli et al. 1998). Note that the $L$-fng expression domain is ventral to and largely nonoverlapping with the Bmp4 positive region. By $12 \mathrm{dpc}$, the $L-f n g$ expression domain splits into a dorsal and a ventral region. The dorsal region is destined to become the macula of the utricle (mu, Fig. 2.5A). The ventral region (mco in Fig. 2.5A) encompasses the future macula of the saccule and the cochlear sensory region, which are distinguishable from each other by 13 $\mathrm{dpc}$ (ms and csr, Fig. 2.5B). By $13 \mathrm{dpc}$, the three cristae also coexpress Bmp4 and $L$-fng (dark and light gray stripes, Fig. $2.5 \mathrm{~B}$ ). Given the role of $L$-fng in the Notch signaling pathway and its role in boundary formation in other tissues, it was suggested that this gene might play a role in hair cell and supporting cell determination as well as in the positioning of sensory organs within the inner ear (Morsli et al. 1998). So far, there is no obvious gross anatomical defect in L-fng knockout mice, suggesting that L-fng is not essential for positioning of sensory organs (Zhang et al. 2000; Johnson and $\mathrm{Wu}$, unpublished results). However, lack of $L$-fng suppresses the increase in the number of inner hair cells in Jagged 2 knockout mice but has no effect on the increase in the number of outer hair cells (Zhang et al. 2000). These results, although not straightforward to interpret, suggest that $L$-fng plays a role in modulating the ligand preference for Notch similar to its role in other systems.

Math1 and NeuroD are also expressed in the presumptive maculae, and loss of Math1 results in the absence of macular sensory hair cells, similar to the phenotype observed in the cristae (see above). In addition, ectopic expression of Math1 in rat utricule cultures induces the conversion of supporting cells into hair cells (Zheng and Gao 2000). Two downstream targets of Notch are expressed in supporting cells of the macula of the utricle, Hes1 and Hes5 (Zheng et al. 2000). Knockout of Hes1 leads to the formation of supernumerary hair cells in the utricle. It is not clear whether Hesl is expressed in the cristae as well (Zheng et al. 2000). Neurogenin1 (Ngn), another bHLH transcription factor, when knocked out affects the development of the utricle, saccule, cochlea, and formation of the eighth ganglion (Ma et al.2000, see below). However, the expression of this gene in prospective sensory organs has not been reported. 


\subsubsection{Non-Notch Pathway}

Comparing published results, the $L$-fng positive domain at the otocyst stage appears to be also positive for Neurotrophin3 (NT-3), and later on NT-3 is expressed in the presumptive maculae and cochlea (Fritzsch et al. 1999). In addition to NT-3, Bdnf is also expressed in the presumptive maculae. Both NT-3 and BDNF are required for the survival of sensory ganglia neurons that innervate the two maculae. Given the anatomical differences between the maculae and cristae, it is surprising that, besides NT-3, no other genes have been reported to be differentially expressed in the maculae and not the cristae. Even otoconin-95, a major component of the otoconia, is not restricted to the utricle and saccule but rather broadly expressed in the nonsensory regions of the inner ear (Verpy et al.1999). However, several genes, although not exclusively expressed in the utricle or saccule, such as Otx1, Otx2, Hmx2 and Hmx3, and Ngn1, when knocked out resulted in an incomplete separation of the utricle and saccule that often affected the development of the two maculae (Wang et al. 1998; Cantos et al. 2000; Ma et al. 2000). Furthermore, even though Otx2 null mutants die too early, before sufficient inner ear development, analysis of mutant mice with Otx1 cDNA inserted into the disrupted Otx2 locus suggests that the role of Otx2 in the development of the saccule and cochlea is not compensated by Otx1 (Cantos et al. 2000).

\subsubsection{Summary}

For simplification, the discussion in the section above was organized into genes that do and do not act in the Notch signaling pathway. However, it is important to note that there may be substantial interplay among the pathways. For example, genes in the Non-Notch category could interact with proneural genes upstream of Notch as well as interact with genes within the Notch signaling pathway. Although such interactions have not been demonstrated during sensory organ formation in the inner ear, in the fruit fly (Drosophila), a wingless signaling pathway component, Dishevelled, has been shown to bind the carboxy-terminal of the Notch receptor and block Notch signaling (Axelrod et al. 1996).

Multiple lines of research indicate that the Notch signaling pathway in inner ear development is more complicated than the simple paradigm presented at the beginning of this section. Although Notch appears to be ubiquitously expressed in the developing inner ear, the ligands for Notch are not. For example, in the chicken otic cup, Jaggedl expression is concentrated in the medial-posterior region, whereas Deltal is expressed in the anterior, neurogenic region, suggesting that these ligands have different functions (Myat et al. 1996; Adam et al. 1998). However, in later stages of inner ear development, Notch ligands and their modulator, L-fng, tend to be coexpressed in the prosensory domains. The temporal sequence of how different Notch ligands interact to achieve cell type diversity is not clear. 
Experiments designed to block the Notch signaling pathway in the developing chicken inner ears show that Jagged1 expression was down-regulated in the sensory regions rather than up-regulated as the conventional model might have predicted (Haddon et al. 1998; Eddison et al. 2000). This result suggests that not all Notch ligands respond in a similar manner to changes in Notch signaling. The complex phenotypes observed in Headturner, Slalom, and Jagged 2 and L-fng double knockouts also lend support to the complexity of the Notch signaling pathway in inner ear development. Furthermore, there are other existing vertebrate, Notch ligands and receptors whose expression patterns and possible functions in the inner ear have not been explored.

Besides the sensory patches, both Jagged1 and Delta1 have restricted patterns of expression in a subpopulation of cells within the endolymphatic sac (Morrison et al. 1999). Thus, most likely, the Notch signaling pathway also plays a role in cell type determination in the endolymphatic sac.

\subsection{Development of the Eighth Cranial Ganglion}

No vestibular sensory organs can function properly without appropriate innervations from the sensory ganglion. Based on analyses of knockout mice, the development of the eighth ganglion (vestibulocochlear ganglion) can also be divided into several phases (for a review, see Fritzsch et al. 1999). First, cells in the anteroventral lateral region of the otic cup or otocyst delaminate from the otic epithelium. Then, these neuroblasts migrate away and undergo further proliferation before coalescing to form a ganglion that later divides to form the vestibular and spiral ganglia (Carney and Couve 1989). The Notch signaling pathway is important for the neuroblast determination, as indicated by the expression of Delta1, Jagged1, and L-fng in the neurogenic domain of the otic cup and otocyst (Adam et al. 1998; Lewis et al. 1998; Morsli et al. 1998). In addition, the number of vestibulocochlear neurons is increased in the zebrafish (B.rerio) mind bomb mutant in which the Notch signaling pathway is postulated to be affected (Haddon et al. 1998). Based on gene expression patterns, the neurogenic region appears to overlap with some prospective sensory domains; however, whether neuroblasts share a common lineage with hair cells and supporting cells within these domains remains to be determined (for a review, see Fekete and $\mathrm{Wu}$ 2002).

Two HLH transcription factors, Ngn1 and NeuroD, have been shown to be important for the early phases of ganglion development (Liu et al. 2000; Ma et al. 2000; Kim et al. 2001). NeuroD knockout mice show defects in neuroblast delamination from the otic epithelium and subsequent neuronal differentiation (Liu et al.2000). As a result, sensory organs are poorly innervated in NeuroD mutants. In Ngn1 knockout mice, inner ear sensory neurons are completely absent (Ma et al. 2000). Presumably, Ngn1 is acting upstream of NeuroD and functions in a pathway similar to NeuroD in the 
development of sensory neurons (Ma et al. 1998). Gene expression analyses of $S h h$ knockout mice as well as a transgenic line that ectopically expresses $S h h$ in the otic vesicle ( $S h h P 1)$ suggest that $S h h$ may act upstream of Ngn1 (Riccomagno et al.2002). In Shh knockout mice, Ngn1 and NeuroD are down-regulated and the cochleovestibular ganglia are greatly reduced in size. In contrast, both Ngnl and NeuroD are up-regulated in ShhP1 mice, which have enlarged ganglia.

Brn3.a/Brn3.0, a POU-domain transcription factor, is expressed in the neuroblasts shortly after they delaminate from the otic epithelium. Loss of Brn3. $a$ affects the differentiation of the sensory neurons, expression of downstream genes such as $\operatorname{Tr} k B$ and $\operatorname{Trk} C$, normal projections, and target innervations (Huang et al. 2001). The expressions of the neurotrophin receptors $\operatorname{Trk} A, \operatorname{Trk} B$, and $\operatorname{Trk} C$ in the differentiating neurons mark a later phase of ganglionic development. The survival of these neurons becomes dependent on neurotrophins such as BDNF and NT-3 synthesized in the differentiating sensory tissues (Fritzsch et al. 1999). Knockout of $B d n f$ or its high-affinity receptor, $\operatorname{Tr} k B$, results in no innervation of the three cristae and poor innervation of the two maculae (Fritzsch et al. 1995; Schimmang et al. 1995; Bianchi et al. 1996). Despite the fact that NT-3 is expressed in the maculae, knockout of NT-3 or its receptor, $\operatorname{Trk} C$, results in only a limited loss of saccular and utricular innervations (Fritzsch et al. 1995; Fritzsch et al. 1997). In contrast to the ganglion cell dependency on sensory tissues for neuronal survival, the development, differentiation, and survival of sensory hair cells appear independent of afferent and efferent innervations (Fritzsch et al. 1997; Silos-Santiago et al. 1997; Liu et al. 2000; Kim et al. 2001).

\subsection{Development of the Semicircular Canals}

Semicircular canal development can be divided into four phases: outgrowth and patterning of the epithelial outpocket, fusion plate formation, resorption, and continued growth of the canal after its formation. The patterning process is most evident by examining the formation of the prospective posterior canal in a series of frontal views of paint-filled chicken inner ears (Fig. 2.6). In chickens, as in mice, the anterior and posterior canals arise from the same vertical outpouch initially, and between embryonic day 4.5 (E4.5) and 5.5, the presumptive posterior canal forms at approximately a right angle to the presumptive anterior canal, possibly via differential growth (Fig. 2.6). By E5.5, the alignment of the anterior and posterior canals is established, but the resorption process for the posterior canal is just beginning and is quite evident by E6. In the chicken, programmed cell death seems to be the main mechanism for the resorption process (Fekete et al. 1997). Ectopic expression of $B c l 2$ that inhibits normal programmed cell death in the chicken resulted in the blockage of canal fusion (Fekete et al. 1997). However, in mice, retraction of cells to the inner margin of the future 


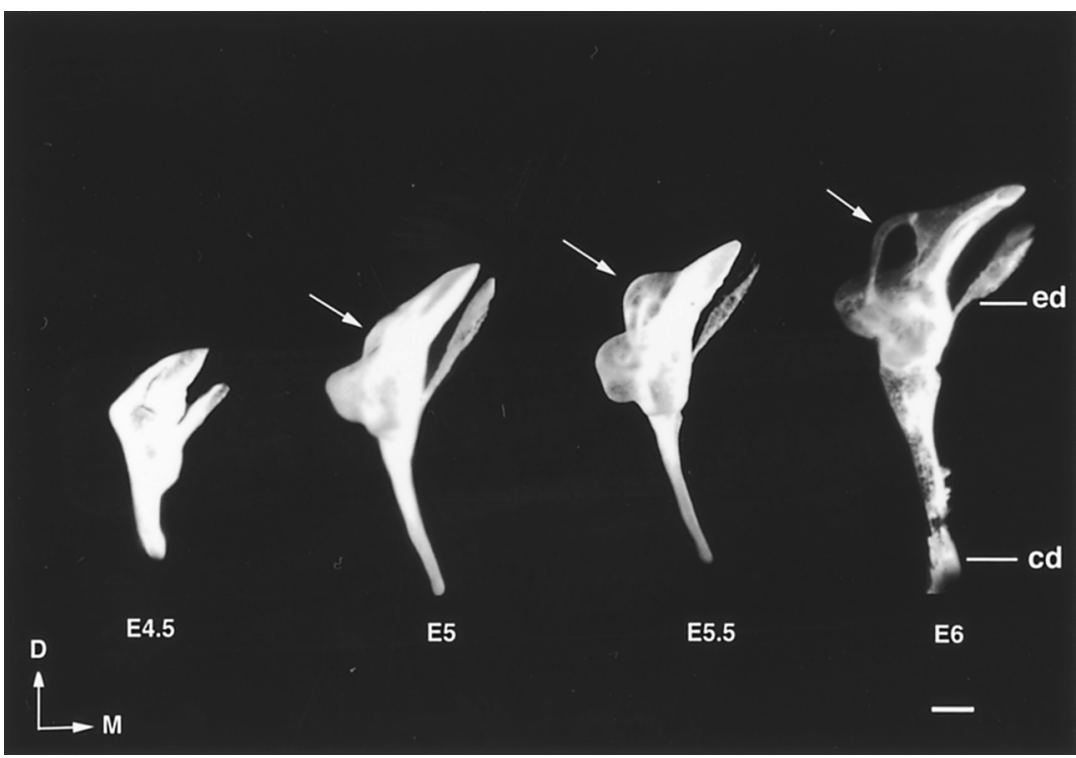

FIGURE 2.6. A series of frontal views of right membranous labyrinths of the chicken from E4.5 to E6. Various steps in the process of posterior canal formation, including outgrowth of the epithelial outpocket (E4.5 to E5), fusion plate formation (E5.5), and resorption (E5.5 to E6), are shown. Arrows point to the developing posterior canal. Abbreviations: ed, endolymphatic duct; cd, cochlear duct. Orientations: $\mathrm{D}$, dorsal; M, medial. Scale bar $=30 \mu \mathrm{m}$.

canal has been proposed to be the main mechanism for the elimination of cells from the center of the canal pouch. Surrounding periotic mesenchyme has also been proposed to be a driving force in the formation of the fusion plate (Salminen et al. 2000; see below).

Thus far, previously identified genes expressed during semicircular canal formation can be roughly divided into two groups: those expressed in the early canal outpocket stage and those expressed slightly later in development (Fig. 2.7). The first group of genes are transcription factors, such as $H m x 2, H m x 3$, and Dlx5, that are activated early at the otic placode stage or shortly after placode formation. These genes are expressed in the epithelium of the canal outpockets and later primarily in the semicircular canals and ampullae. Knockouts of these genes affect the normal development of ampullae and canals (Hadrys et al. 1998; Wang et al. 1998; Acampora et al. 1999b; Depew et al. 1999). Hmx2 and Hmx3 are members of a homeoboxcontaining family of transcription factors that are distinct from Hox and other homeobox-containing genes. Similar to Hox genes, Hmx are evolutionarily conserved from fruit flies (Drosophila) to humans. There are three 


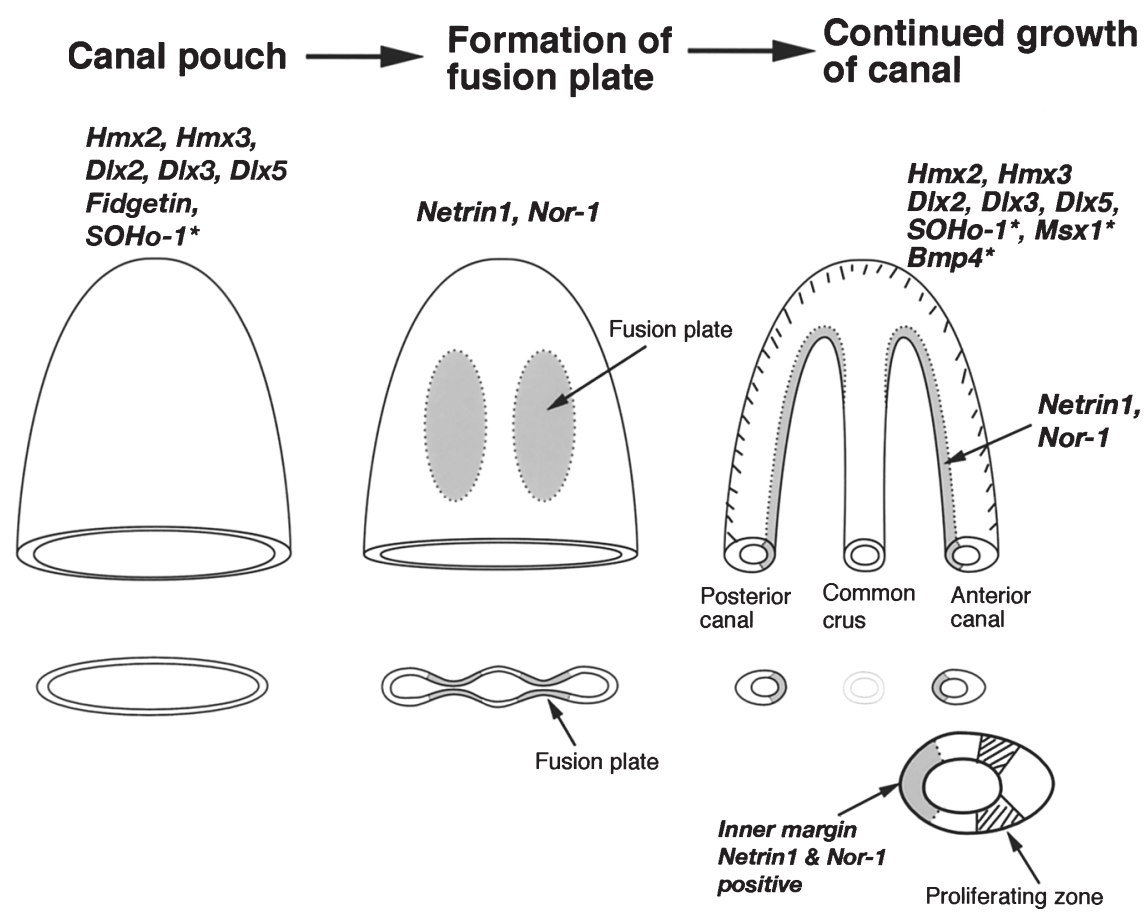

FIGURE 2.7. A schematic diagram summarizing genes expressed during development of the semicircular canals. The lower panel is a cross-sectional view of the upper panel. An enlarged cross-sectional view of a canal is shown on the lower right. Genes such as Dlx5 and Hmx3 are expressed in the canal outpocket, whereas Netrin 1 and Nor-1 are expressed in the central region of the outpocket that is destined to form the fusion plate. Once the canals are formed, Netrin 1 and Nor-1 are expressed in the inner margin of the canals, and other genes such as $H m x 3$ are broadly expressed in the canal epithelia. Asterisks represent gene expression patterns reported in the chicken. Refer to the legend of Figure 2.2 for abbreviations and orientations.

members in the mammalian genome: $H m x 1, H m x 2$, and $H m x 3$. Both $H m x 2$ and $H m x 3$ are expressed in the developing mouse inner ear, with $H m x 3$ having a slightly earlier onset of expression than Hmx2 starting at the otic placode stage (Rinkwitz-Brandt et al. 1995, 1996; Wang et al. 2001). Targeted deletions of Hmx3 have been reported by two independent laboratories. Bober's group reported a reduction in the size of the anterior canal, missing posterior and lateral canals, and the absence of a lateral crista in their Nkx5.1/Hmx3 knockout mice (Hadrys et al. 1998). Lufkin's group observed a much milder canal phenotype in their Hmx3 mutants: only the lateral crista and ampulla were missing. In addition, the two maculae were fused (Wang et al. 1998). However, they reported a much 
more severe inner ear phenotype for the Hmx2 knockout: loss of all three canals and their associated cristae, as well as a fused utriculosaccular chamber (Wang et al. 2001). In fact, the phenotypes of the Hmx2 knockout closely resembled the phenotypes observed in the Hmx3 knockout mice generated in the Bober laboratory. A negative effect of the inserted $\mathrm{Hmx3}^{-}$ Pkneo allele on the closely linked Hmx2 gene in Bober's Hmx3 knockout line was put forth as a plausible explanation for these paradoxical results (Wang et al. 2001). Nevertheless, these combined results suggest that $H m x 2$ and Hmx3 both have unique and overlapping functions in vestibular development.

Dlx 5 belongs to a family of homeobox-containing genes that is related to the Distal-less $(D l l)$ gene of the fruit fly (Drosophila). In Drosophila, Dll is required for correct development of the distal portion of the legs, antennae, and mouth parts (Cohen et al. 1989; O'Hara et al. 1993). In mice, there are at least six Dlx genes, four of which are expressed in the developing inner ear (Robinson and Mahon 1994; Simeone et al. 1994; Acampora et al. 1999b; Depew et al.1999). So far, only a knockout of Dlx 5 has been reported to result in malformations of the inner ear, including a smaller lateral canal and missing anterior and posterior canals (Acampora et al. 1999b; Depew et al. 1999). The three cristae are malformed, and the two maculae are also reduced in size (Merlo et al. 2002).

In addition to transcription factors, Fidgetin, a chaperone protein that is a member of the AAA (ATPase associated with different cellular activities) family of proteins, was also identified to be important for proper canal formation. AAA proteins are a group of ATPases that share common sequence features in addition to an ATP-binding motif. These proteins participate in a variety of cellular functions such as cell-cycle regulation, proteolysis, and membrane fusion (Patel and Latterich 1998). Using a positional cloning approach, Fidgetin was identified as the gene causing the inner ear and retinal phenotypes in the spontaneous mouse mutant fidget (Cox et al. 2000). In the inner ear, Fidgetin is expressed in the canal outpocket and the cochlear duct (Cox et al. 2000). Fidget mice are missing the lateral canal and crista and have malformed anterior and posterior canals (Truslove 1956). The function of Fidgetin in mediating canal development remains unclear. It has a unique N-terminal domain compared with other members of its family and, unlike other members of the family, is not predicted to have ATPase activity.

The expression of a second group of genes is initiated slightly later during canal formation. These genes include Netrin 1 and Nor-1, which are expressed in the central region of the canal outpocket that is destined to form the fusion plate (Fig. 2.7). Netrin 1 is a laminin-like, secreted molecule that functions as an axonal guidance molecule in the brain (Livesey 1999). In the inner ear, Netrin 1 knockout mice fail to form a fusion plate and, as a result, no resorption takes place in the prospective canals. It was proposed that the lack of proliferation in the surrounding mesenchyme fails to drive 
the opposing otic epithelia of the outpocket to come together to form the fusion plate (Salminen et al. 2000).

Nor-1 is a member of the nuclear receptor family of transcription factors. Members of this subclass of nuclear receptors are thought to function as constitutively active transcription factors (Maruyama et al. 1998). A ligand for Nor-1, if one exists, has not been identified. Although the expression patterns of Netrin 1 and Nor-1 in the inner ear are similar (highest in the fusion plate region), loss of Nor-1 function does not affect canal resorption. In Nor-1 knockout mice, the canals and ampullae are smaller than in wildtype mice (Ponnio et al. 2002). Cell proliferation is initially widespread in the prospective canal region, but after canal formation it becomes restricted to two regions of the canal (Fig. 2.7; Chang et al. 1999; Ponnio et al. 2002). The loss of Nor-1 affected the proliferation and continual growth of all three canals and ampullae. Molecularly, it is not clear how Nor-1 regulates cell proliferation in canals because Nor-1 does not appear to be expressed in the proliferative zones.

Furthermore, in contrast to the expression of Netrin 1 and Nor-1 in the inner margin of the canals, several genes are asymmetrically distributed in the outer margins, such as SOHo-1 (sensory organ homeobox), Msx1, and Bmp4 (Kiernan et al. 1997; Chang et al. 1999). Together, these results indicate that the semicircular canals are molecularly more complex than their simple tube-shaped structures imply.

In addition to the two groups of genes mentioned above, Otx1 and $S h h$ are specifically important for the development of the lateral canal. In addition, Gli3, a negative regulator of Shh functions, also plays a role in canal development. In mouse mutant Extratoes, in which the Gli3 gene is mutated, the lateral canal is missing and the anterior canal is truncated (Johnson 1967). Detailed expression of Gli3 in the inner ear has not been reported, but its expression in the periotic mesenchyme has been demonstrated (Hui et al. 1994). Therefore, Gli3 is another candidate gene that may influence canal development via a mesenchymal-epithelial signaling mechanism.

The anterior and posterior semicircular canals are connected to the common crus at one end. It is not clear whether the formation of the common crus is governed by common crus-specific molecules or is the consequence of resorption in the surrounding tissues. So far, there is no report of any gene that is specifically expressed in the common crus and not in the canals. However, two lines of evidence suggest that the common crus development is regulated differently from that of the canals. First, there has been a report of a patient with Goldenhar syndrome who has no common crus but has intact anterior and posterior canals (Manfre et al. 1997). Second, by implanting beads soaked with retinoic acid in the developing chicken otocyst, it has been shown that formation of the semicircular canal is sensitive to retinoic acid treatment in a dose-dependent manner (Choo et al. 1998). In the most severe cases, where none of the semicircular canals 
formed properly, the common crus was still intact, suggesting that genes regulating common crus development are insensitive to retinoic acid treatment and thus might be different from those governing canal formation.

A given gene could function in multiple phases of canal formation. For example, BMPs are important for multiple stages of canal development in the chicken. Noggin, an antagonist of BMPs, in particular BMP2 and BMP4, was delivered to the developing chicken otocyst using either Nogginproducing cells, beads soaked with Noggin protein, or a replicationcompetent avian retrovirus encoding the Noggin cDNA (Chang et al. 1999; Gerlach et al. 2000). These treatments consistently result in truncations of the canals and sometimes involve malformations of the ampullae. The defect in the canal formation is evident at the canal outpocket phase. Interestingly, even after the canals are formed at E7, implantation of beads soaked with Noggin protein leads to canal truncation 2 days later, indicating that the continual presence of BMPs is important for canal development. More recent data suggest that Noggin mediates its effect on canal development by blocking the action of BMP2 (Chang et al. 2002).

\subsection{Relationship of Sensory and Nonsensory Tissue Development}

Even though distinct molecular mechanisms govern the differentiation of sensory versus nonsensory components of the inner ear, the two pathways are most likely coordinated during early developmental stages to ensure a functional end product. One way that this can be accomplished molecularly is to activate genes that can initiate different developmental pathways in different tissues simultaneously. For example, Otx1 is activated in both the prospective lateral ampulla and canal at the same time of development and may serve to synchronize their development. Another way to mediate the coordinated development of sensory and nonsensory tissues is through signaling molecules such as growth factors released by either tissue that couple the two developmental programs. Under these models, one would predict that most morphogenetic mutants would have both sensory and nonsensory defects. Indeed, most mutants, both in mice and zebrafish (B.rerio), that lack a sensory component such as a crista also show defects in the corresponding canal (Malicki et al. 1996; Whitfield et al. 1996). However, the reverse is not true. There are mutants that have defective canals but intact cristae, such as eselsohr in zebrafish (B.rerio) and Rotating and Extratoes in mice (Deol 1983; Whitfield et al. 1996). The existence of such mutants suggests that sensory tissues may play a dominant role in coordinating inner ear development by specifying nonsensory tissue formation. Axial rotation experiments performed in the chicken are consistent with this idea and suggest that the specification of sensory structures precedes specification of nonsensory structures (Wu et al. 1998). By reversing the 
anteroposterior $(\mathrm{A} / \mathrm{P})$ axis of the otocyst relative to the body axis, these studies indicate that the $\mathrm{A} / \mathrm{P}$ axes of the sensory organs are fixed during a development period when nonsensory components of the inner ear remain unspecified.

Identification of signaling molecules that coordinate the two developmental pathways is essential to understanding the development of this complex organ. However, it is not always straightforward to extrapolate the function of a given gene based on mutation analyses or expression patterns alone. For example, Bmp 4 is expressed in both sensory and nonsensory components of the inner ear during development. Furthermore, the ubiquitous expression of its receptors suggests that BMP4 could affect multiple target tissues. A more revealing expression pattern might be that of $\mathrm{FgflO}$ and EphB2. Fgf10 is predominantly expressed in the sensory tissues, whereas its receptor, Fgfr-2 (IIIb) is exclusively expressed in the surrounding nonsensory component of the inner ear (Pirvola et al. 2000). So far, a majority of the phenotypes reported for $\mathrm{Fgf10}$ knockout mice are consistent with Fgf10's postulated role in mediating nonsensory tissue development. However, the associated sensory phenotypes observed in Fgf10 knockout mice suggest that other FGF receptors besides FGFR-2 (IIIb) are responsible for mediating this development (Pauley et al. 2003).

Eph and its ligand ephrin participate in bidirectional signaling cascades that operate in both receptor- and ligand-expressing cells. These molecules are important for multiple cell-cell communication processes, including axonal guidance, boundary formation in the brain, and vascular development (Flanagan and Vanderhaeghen 1998; Frisen et al. 1999). In the inner ear, EphB2, a tyrosine kinase receptor, is expressed in the nonsensory, vestibular dark cells bordering the sensory tissues of the cristae and maculae. In contrast, its putative ligand, ephrinB2, is expressed in the supporting cells of the sensory organs. EphB2 knockout mice show a defect in fluid homeostasis in the endolymph, and their vestibular dark cells are disorganized (Cowan et al. 2000; see below). A possible role of ephrinB2expressing cells in the development or differentiation of EphB2-expressing cells warrants further investigation.

Although it appears that sensory tissue induction precedes nonsensory tissue induction, it is possible that once nonsensory tissues are specified, genes expressed in these tissues feed back on sensory tissue and affect its development. The best supporting evidence for this comes from the analysis of the Otxl knockout mice. Otxl is not expressed in the presumptive maculae of the utricle and saccule; however, its expression domain abuts the lateral region of both maculae. The absence of Otx1 results in incomplete separation of the maculae of the utricle and saccule, which could result from abnormal morphogenesis of the surrounding nonsensory tissues. Alternatively, Otx1 produced by nonsensory tissue may lead to the activation of factors that in turn affect sensory development (Morsli et al. 1999; Fritzsch et al. 2001). 


\subsection{Genes that Affect Fluid Homeostasis}

Apart from genes that are important for patterning of the vestibular apparatus, there are genes that regulate fluid homeostasis of the endolymph. Absence of these gene products can also lead to changes in the shape of the membranous labyrinth and deficits in vestibular system function (Table 2.2).

The endolymph that fills the membranous labyrinth has an unusually high potassium ion concentration, which is important for proper signal transduction in sensory hair cells. It has been proposed that, in the cochlea, potassium ions enter the hair cells during the process of mechanotransduction and are subsequently taken up by the supporting cells and recycled back into the endolymph via the stria vascularis in the lateral wall of the cochlear duct (Kikuchi et al. 1995; Spicer and Schulte 1998). Similar mechanisms may be involved in the vestibular apparatus; light and dark cells with secretory and resorption functions are located in close proximity to each of the vestibular sensory organs (Dohlman 1961).

TABLE 2.2. Genes affecting fluid homeostasis of the inner ear.

\begin{tabular}{|c|c|c|c|c|}
\hline \multirow[b]{2}{*}{ Gene } & \multirow[b]{2}{*}{ Type of protein } & \multirow[b]{2}{*}{ Distribution in the inner ear } & \multicolumn{2}{|c|}{ Functional deficits } \\
\hline & & & Vestibular & Cochlear \\
\hline $\begin{array}{l}\text { KCNE1/ } \\
\text { isk }\end{array}$ & $\begin{array}{l}\text { protein that } \\
\text { coassembles with } \mathrm{K}^{+} \\
\text {channel subunits }\end{array}$ & stria vascularis & + & + \\
\hline Ephb2 & $\begin{array}{l}\text { tyrosine kinase } \\
\text { receptor }\end{array}$ & $\begin{array}{l}\text { stria vascularis, dark cells of } \\
\text { vestibule }\end{array}$ & + & - \\
\hline $\begin{array}{l}\text { Kvlqt1/ } \\
K C N Q 1\end{array}$ & $\mathrm{~K}^{+}$channel & stria vascularis & + & + \\
\hline$K C N Q 4^{*}$ & $\mathrm{~K}^{+}$channel & $\begin{array}{l}\text { outer hair cells of the } \\
\text { cochlea; hair cells of } \\
\text { vestibular organs }\end{array}$ & $?$ & $+*$ \\
\hline Pendrin & anion transporter & $\begin{array}{l}\text { endolymphatic sac and duct; } \\
\text { between macula utriculi and } \\
\text { anterior and lateral cristae; } \\
\text { nonsensory region of the } \\
\text { saccule; external sulcus region } \\
\text { of the cochlea }\end{array}$ & + & + \\
\hline Slc12a2 & $\begin{array}{l}\mathrm{Na}^{+}-\mathrm{K}^{+}-\mathrm{Cl}^{2-} \\
\text { transporter }\end{array}$ & $\begin{array}{l}\text { marginal cells of stria } \\
\text { vascularis; spiral ligament; } \\
\text { dark cells of vestibule }\end{array}$ & + & + \\
\hline Slc12a7 & $\mathrm{K}-\mathrm{Cl}^{-}$cotransporter & $\begin{array}{l}\text { supporting cells for inner and } \\
\text { outer hair cells }\end{array}$ & - & + \\
\hline
\end{tabular}

* No animal model available yet; the functional deficits are based on data from humans. 
$K C N Q 4$ encodes a potassium channel and is primarily expressed in the outer hair cells of the cochlea and type I hair cells of the vestibular organs (Kharkovets et al. 2000). Immunostaining studies localized this protein to the basolateral membrane of the sensory hair cells, supporting its postulated role in recycling potassium ions from hair cells back to the endolymph. Mutations in KCNQ4 cause dominant, progressive deafness in humans. However, no animal models for this gene are yet available (Kubisch et al. 1999). More recently, a K-Cl cotransporter, Kcc4, that is expressed in the Deiters' and phalangeal cells has been postulated to participate in the recycling of potassium ions that have exited hair cells into supporting cells (Boettger et al.2002). Mice lacking Kcc4 function are deaf and display renal tubular acidosis.

So far, three genes expressed in the stria vascularis region are believed to be important for recycling potassium ions into the endolymph. Kcnq1(Kvlqt1) or isk (KCNE1) are both expressed in the marginal cells of the stria (Sakagami et al. 1991; Wangemann et al. 1995; Neyroud et al.1997). Kcnq1 encodes a potassium channel subunit in the same family as Kcnq4. Isk encodes a transmembrane protein that assembles with potassium channel subunits including Kcnq1. Mutations in both KCNQ1 and KCNE1 cause Jervell and Lange-Nielsen syndrome in humans (Neyroud et al. 1997; Schulze-Bahr et al. 1997), a syndrome associated with ventricular tachyarrhythmias of the heart and deafness. Knockout mouse models for both genes show a collapsed membranous labyrinth indicative of endolymph secretion failure and disruption of fluid homeostasis in the inner ear (Vetter et al. 1996; Lee et al. 2000; Casimiro et al. 2001). A spontaneous mouse mutant, Punk Rocker, with a nonsense mutation in Kcne1 that results in a truncated protein, also shows an inner ear phenotype similar to the knockout mice (Letts et al. 2000).

Slc12a2, which encodes a $\mathrm{K}-\mathrm{Na}-\mathrm{Cl}$ cotransporter, is also postulated to participate in recycling potassium ions back into the endolymph. This protein is expressed in the basolateral membrane of the marginal cells in the stria vascularis, fibrocytes in the spiral ligament, and dark cells of the vestibule (Crouch et al. 1997; Goto et al. 1997; Mizuta et al. 1997). Three mouse models are available for Slc12a2: a targeted deletion mutant; a radiation-induced mutant (Shaker-with-syndactylism $(s y)$ ) with a deletion that includes the Slc12a2 locus; and an allele of sy, sy ${ }^{n s}$ (Shaker with no syndactylism), that has a frame-shift mutation in Slc12a2 (Delpire et al. 1999; Dixon et al. 1999). All three mutant lines are deaf, with waltzer/shaker behavior indicative of vestibular deficits. In addition, their membranous labyrinths are collapsed, indicating a problem with endolymph secretion (Delpire et al. 1999; Dixon et al. 1999).

As indicated earlier, lack of EphB2 also causes reduction of endolymph production. EphB2 is postulated to regulate fluid homeostasis by interacting indirectly with anion exchangers and aquaporins (Cowan et al. 2000). Interestingly, despite the expression of EphB2 in the nonsensory compo- 
nents of both the vestibule and cochlea, EphB2 knockout mice display vestibular dysfunction but are not deaf. Furthermore, their cochlear ducts appear normal, suggesting that fluid homeostasis in the cochlea is not affected. Because the membranous labyrinth of the mouse is largely two separate compartments by $16.5 \mathrm{dpc}$, genes that affect fluid homoestasis may not necessarily affect both auditory and vestibular functions, depending on the expression domain and mode of action of a given gene (Cantos et al. 2000).

Another example of a gene that regulates fluid homeostasis is Pendrin $(P d s)$, which is responsible for causing Pendred syndrome as well as a nonsyndromic form of deafness in humans (Everett et al. 1997; Li et al. 1998). Patients with Pendred syndrome have sensorineural deafness and goiter. Widened vestibular aqueducts are commonly found in the inner ears of these patients. In addition, cochleae of Mondini phenotype characterized by incomplete coiling have also been described (Johnsen et al. 1986; Cremers et al. 1998).

In the mouse, $P d s$ mRNA is found in the inner ear, thyroid, and kidney (Everett et al. 1997; Everett et al. 1999). Within the inner ear, $P d s$ is highly expressed in the endolymphatic sac and duct. It is also expressed in nonsensory regions of the utricle and saccule and the external sulcus region (adjacent to the stria vascularis) of the cochlea (Everett et al. 1999). The expression of $P d s$ is first activated in the endolymphatic sac and duct around $13 \mathrm{dpc} . P d s$ knockout mice are deaf and show a variable spectrum of vestibular problems such as circling, head tilting, and bobbing behaviors (Everett et al. 2001). Unlike other knockout mice that have defects in fluid homeostasis, $P d s-/-$ mutants show swelling of the membranous labyrinth instead of shrinkage. The endolymphatic duct and sac are the first structures to swell, starting at $15 \mathrm{dpc}$ (Fig. 2.8A,B, arrows). The swelling later spreads into the vestibular and cochlear regions. The deafness and balancing problems in these mice are most likely due to sensory hair-cell degeneration resulting from an ionic imbalance within the endolymph (Everett et al. 2001). Functional studies in frog (Xenopus) oocytes suggest that PENDRIN is a chloride and iodide transporter (Scott et al. 1999). However, whether chloride and/or possibly other anions are being transported by PENDRIN within the inner ear remains to be directly determined.

In the mouse inner ear, as morphogenesis proceeds, the connection between the utricle and saccule becomes restricted such that, by $16.5 \mathrm{dpc}$, the endolymphatic sac and duct, as well as the saccule and cochlea, are one continuous chamber, and the utricle and three canals and their ampullae are joined in another chamber (Cantos et al. 2000). Figure 2.8C illustrates a paint-filled inner ear that has been injected in the endolymphatic sac at P1. Only the saccule and cochlea, but not the utricle or the rest of the labyrinth, were filled with paint from such an injection. Despite the prenatal malformations and swelling of the membranous labyrinth of the $P d s$ knockout mice, a similar paint-fill pattern was observed in Pds mutants, 

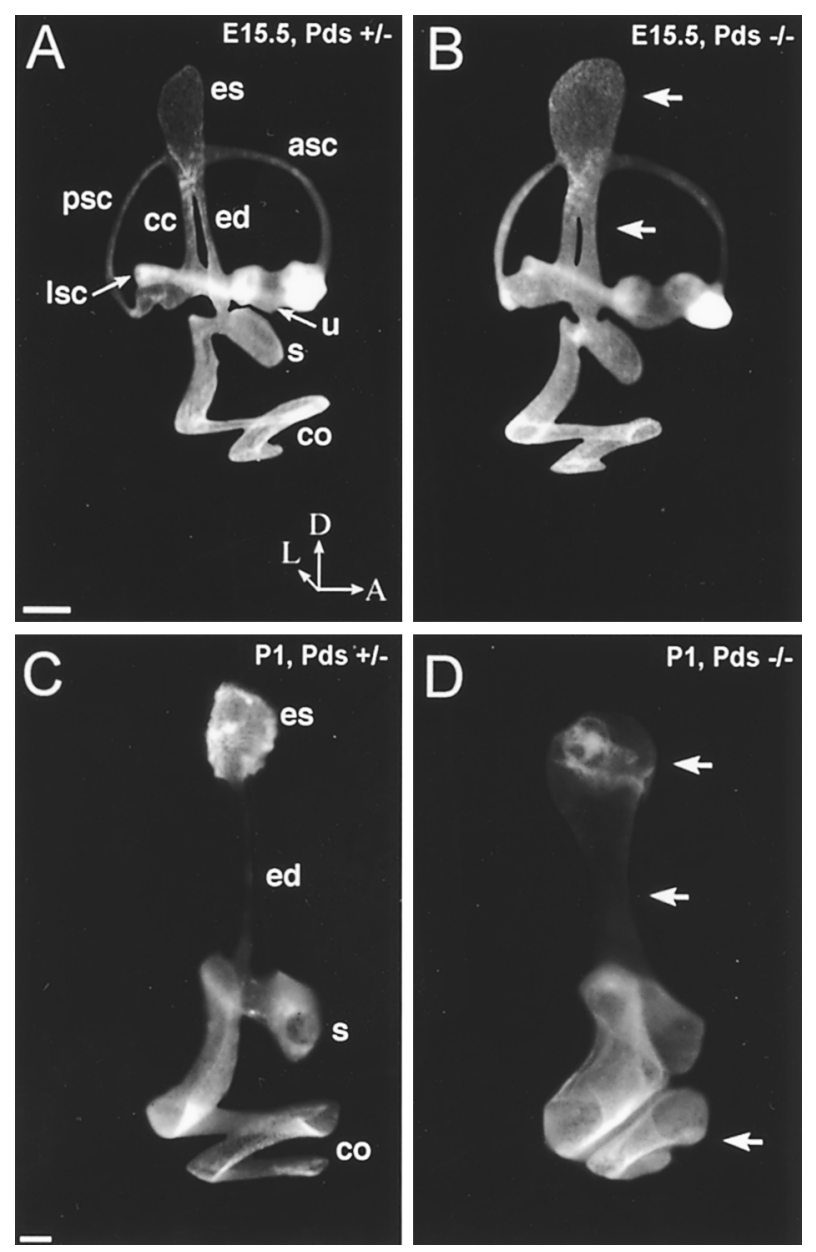

Figure 2.8. Paint-filled mouse membranous labyrinths of the wild type (A, C) and Pendrin -/- mutant (B, D). Swelling of the membranous labyrinth of Pnd mutants is first apparent in the endolymphatic duct and sac at $15.5 \mathrm{dpc}$ (arrows in B). Latex paint solution is injected only into the endolymphatic sac in wild-type (C) and mutant (D) inner ears at P1. Injection into the endolymphatic sac only fills the sac and its duct, the saccule, and cochlea (C). Despite the enlarged membranous labyrinth in Pnd null mutants, injection of latex paint to the endolymphatic sac shows a pattern similar to the wild type, indicating that the utricle and saccule are in separate compartments (D). For abbreviations, see Figure 2.2. Scale bar $=$ $100 \mu \mathrm{m}$. 
indicating that the utricle and saccule still separated into individual compartments (Fig. 2.8D). This is in contrast to the morphogenetic mutants such as Hmx2, Hmx3, Ngn1, Otx1, and Otx2 knockouts, where the utricle and saccule fail to separate from each other (Wang et al.1998; Morsli et al.1999; Ma et al. 2000).

Furthermore, because of the unique ionic composition and high resting potential of the endolymph, the epithelial cells of the membranous labyrinth might require specialized intercellular communication networks and proper "sealing" from their surrounding tissues. Consistent with this hypothesis, mutations in genes encoding for gap junction proteins such as connexin 26 and 31 and tight junction proteins such as claudin 14 have been implicated in causing human deafness (Wilcox et al. 2001; for a review, see Steel et al. 2002). The etiologies of these human syndromes will be apparent as more animal models become available.

\section{Conclusion}

Two areas of inner ear development have not been discussed thus far: otic induction and differentiation of sensory hair cells. Fgf19 and Wnt-8c are implicated in otic induction in the chicken (Ladher et al. 2000; Vendrell et al. 2000); Fgf3 and $F g f 8$ are implicated in otic induction in zebrafish (B. rerio) (Phillips et al. 2001; Leger and Brand 2002; Maroon et al. 2002, whereas $\mathrm{Fgf3}$ and $\mathrm{FgflO}$ are important for otic induction in mice (Wright and Mansour 2003). Recent reviews on otic induction and related topics can be found in a special issue of Journal of Neurobiology (Kil and Collazo 2002; Noramly and Grainger 2002; Whitfield 2002). Furthermore, many genes have been identified to be essential for hair cell development/differentiation, such as Pou4f3 (Brn3.1), myosinVIIa, Espin, and Cadherins. Mutations of these genes lead to vestibular and auditory deficits in both humans and mice. Readers are referred to recent reviews on these topics (Steel and Kros 2001; Caldwell and Eberl 2002; Steel et al. 2002). For additional readings on genes associated with morphogenesis of the inner ear, readers are referred to two excellent reviews by Anagnostopoulos (Anagnostopoulos 2002) and Kiernan et al. (Kiernan et al. 2002).

Correlating a specific gene's knockout phenotype with its expression pattern is essential to understanding its role in inner ear development. However, multiple examples given here show that a gene's expression pattern does not necessarily predict the phenotype that results from loss of the gene product. Dlx5 and Netrin1, for example, are both equivalently expressed in each of the three presumptive canals; however, knockouts of these genes show different degrees of phenotypic severity among the three canals. Also, although loss of Math1 affected hair cell formation in all inner ear sensory organs, Jagged1 and Jagged 2 seem to have differential effects on hair cell formation in different sensory organs. 
Such disparities may be explained by differential control and functional redundancy. Despite the apparent morphological similarities in the formation of the canals and the arrangement of hair cells and supporting cells in different sensory organs, the molecular mechanisms underlying each of these processes are most likely regulated differently. Furthermore, the developmental pathways for inner ear structures are likely to be influenced by a variety of genes whose expression patterns and actions within the individual inner ear structures have thus far not been assessed. Finally, the differential expression and/or efficacy of functionally redundant genes in the different inner ear structures may determine the extent to which the knockout of any given gene affects a particular structure. For example, four out of the six $D l x$ genes are expressed in the inner ear; one or more of these genes could share a redundant function with Dlx5 in the formation of the lateral canal.

The creation of multiple and conditional knockouts in mice will continue to be a powerful tool for molecularly unraveling the organogenesis of this complex organ. With the aid of the mouse genome project, the identification of genes responsible for existing and upcoming mutants will be expedited. Contributions from other genetic models such as zebrafish (B. rerio) and models that are ideal for misexpression studies and embryonic manipulations, such as the chicken and frog (Xenopus) will also be indispensable. An in-depth molecular understanding of this complex organ during development will pave the way for better strategies to alleviate vestibular and auditory deficits associated with this sense organ.

Acknowledgments. The authors wish to thank Quianna Burton, Jenny Bai, and Michael Mulheisen for figure preparation and three-dimensional reconstructions and Dr. Susan Sullivan for critical reading of the manuscript and discussions. The three-dimensional reconstruction software was provided by the Biocomputation Center at Ames Research Center, NASA. The authors also wish to thank Drs. Bernd Fritzsch, MengQing Xiang, Amy Kiernan, and Suzanne Mansour for preprints prior to publication. Data provided in Figure 2.8 are done in collaboration with Lorraine Everett and Eric Green in NHGRI, NIH.

\section{References}

Abdelhak S, Kalatzis V, Heilig R, Compain S, et al. (1997) A human homologue of the Drosophila eyes absent gene underlies branchio-oto-renal (BOR) syndrome and identifies a novel gene family. Nat Genet 15:157-164.

Acampora D, Mazan S, Lallemand Y, Avantaggiato V, et al. (1995) Forebrain and midbrain regions are deleted in Otx2-l- mutants due to a defective anterior neuroectoderm specification during gastrulation. Development 121:3279-3290.

Acampora D, Mazan S, Avantaggiato V, Barone P, et al. (1996) Epilepsy and brain abnormalities in mice lacking the Otx1 gene. Nat Genet 14:218-222. 
Acampora D, Avantaggiato V, Tuorto F, Barone P, et al. (1999a) Differential transcriptional control as the major molecular event in generating Otx1-/- and Otx2-/- divergent phenotypes. Development 126:1417-1426.

Acampora D, Merlo GR, Paleari L, Zerega B, et al. (1999b) Craniofacial, vestibular, and bone defects in mice lacking the Distal-less-related gene Dlx5. Development 126:3795-3809.

Adam J, Myat A, Le Roux I, Eddison M, et al. (1998) Cell fate choices and the expression of Notch, Delta and Serrate homologues in the chick inner ear: parallels with Drosophila sense-organ development. Development 125:4645-4654.

Alavizadeh A, Kiernan AE, Nolan P, Lo C, et al. (2001) The Wheels mutation in the mouse causes vascular, hindbrain, and inner ear defects. Dev Biol 234:244-260.

Anagnostopoulos A (2002) A compendium of mouse knockouts with inner ear defects. Trends Genet 18:S21-S38.

Anderson DJ, Jan YN (1997) The determination of the neuronal phenotype. In: Cowan WM, Jessell TM, Zipursky SL (eds) Molecular and Cellular Approaches to Neural Development. New York: Oxford University Press, pp. 26-63.

Ang SL, Jin O, Rhinn M, Daigle N, et al. (1996) A targeted mouse Otx2 mutation leads to severe defects in gastrulation and formation of axial mesoderm and to deletion of rostral brain. Development 122:243-252.

Artavanis-Tsakonas S, Simpson P (1991) Choosing a cell fate: a view from the Notch locus. Trends Genet 7:403-408.

Artavanis-Tsakonas S, Rand MD, Lake RJ (1999) Notch signaling: cell fate control and signal integration in development. Science 284:770-776.

Axelrod JD, Matsuno K, Artavanis-Tsakonas S, Perrimon N (1996) Interaction between Wingless and Notch signaling pathways mediated by dishevelled. Science 271:1826-1832.

Bermingham NA, Hassan BA, Price SD, Vollrath MA, et al. (1999) Math1: an essential gene for the generation of inner ear hair cells. Science 284:1837-1841.

Bianchi LM, Conover JC, Fritzsch B, DeChiara T, et al. (1996) Degeneration of vestibular neurons in late embryogenesis of both heterozygous and homozygous BDNF null mutant mice. Development 122:1965-1973.

Bissonnette JP, Fekete DM (1996) Standard atlas of the gross anatomy of the developing inner ear of the chicken. J Comp Neurol 368:620-630.

Boettger T, Hubner CA, Maier H, Rust MB, et al. (2002) Deafness and renal tubular acidosis in mice lacking the $\mathrm{K}-\mathrm{Cl}$ co-transporter Kcc4. Nature 416:874-878.

Brigande JV, Iten LE, Fekete DM (2000a) A fate map of chick otic cup closure reveals lineage boundaries in the dorsal otocyst. Dev Biol 227:256-270.

Brigande JV, Kiernan AE, Gao X, Iten LE, et al. (2000b) Molecular genetics of pattern formation in the inner ear: do compartment boundaries play a role? Proc Natl Acad Sci USA 97:11700-11706.

Caldwell JC, Eberl DF (2002) Towards a molecular understanding of Drosophila hearing. J Neurobiol 53:172-189.

Cantos R, Cole LK, Acampora D, Simeone A, et al. (2000) Patterning of the mammalian cochlea. Proc Natl Acad Sci USA 97:11707-11713.

Carney PR, Couve E (1989) Cell polarity changes and migration during early development of the avian peripheral auditory system. Anat Rec 225:156-164.

Carpenter EM, Goddard JM, Chisaka O, Manley NR, et al. (1993) Loss of Hox-A1 (Hox-1.6) function results in the reorganization of the murine hindbrain. Development 118:1063-1075. 
Casimiro MC, Knollmann BC, Ebert SN, Vary JC Jr, et al. (2001) Targeted disruption of the Kcnq1 gene produces a mouse model of Jervell and Lange-Nielsen syndrome. Proc Natl Acad Sci USA 98:2526-2531.

Chang W, Nunes FD, De Jesus-Escobar JM, Harland R, et al. (1999) Ectopic noggin blocks sensory and nonsensory organ morphogenesis in the chicken inner ear. Dev Biol 216:369-381.

Chang W, ten Dijke P, Wu DK (2002) BMP pathways are involved in otic capsule formation and epithelial-mesenchymal signaling in the developing chicken inner ear. Dev Biol 251:380-394.

Chen P, Johnson JE, Zoghbi HY, Segil N (2002) The role of Math1 in inner ear development: uncoupling the establishment of the sensory primordium from hair cell fate determination. Development 129:2495-2505.

Chen R, Amoui M, Zhang Z, Mardon G (1997) Dachshund and eyes absent proteins form a complex and function synergistically to induce ectopic eye development in Drosophila. Cell 91:893-903.

Chen Y, Bei M, Woo I, Satokata I, et al. (1996) Msx1 controls inductive signaling in mammalian tooth morphogenesis. Development 122:3035-3044.

Choo D, Sanne JL, Wu DK (1998) The differential sensitivities of inner ear structures to retinoic acid during development. Dev Biol 204:136-150.

Cohen SM, Bronner G, Kuttner F, Jurgens G, et al. (1989) Distal-less encodes a homoeodomain protein required for limb development in Drosophila. Nature 338:432-434.

Cole LK, Le Roux I, Nunes F, Laufer E, et al. (2000) Sensory organ generation in the chicken inner ear: contributions of bone morphogenetic protein 4 , serrate 1 , and lunatic fringe. J Comp Neurol 424:509-520.

Cordes SP, Barsh GS (1994) The mouse segmentation gene $k r$ encodes a novel basic domain-leucine zipper transcription factor. Cell 79:1025-1034.

Cowan CA, Yokoyama N, Bianchi LM, Henkemeyer M, et al. (2000) EphB2 guides axons at the midline and is necessary for normal vestibular function. Neuron 26:417-430.

Cox GA, Mahaffey CL, Nystuen A, Letts VA, et al. (2000) The mouse fidgetin gene defines a new role for AAA family proteins in mammalian development. Nat Genet 26:198-202.

Cremers CW, Admiraal RJ, Huygen PL, Bolder C, et al. (1998) Progressive hearing loss, hypoplasia of the cochlea and widened vestibular aqueducts are very common features in Pendred's syndrome. Int J Pediatr Otorhinolaryngol 45:113-123.

Crouch JJ, Sakaguchi N, Lytle C, Schulte BA (1997) Immunohistochemical localization of the $\mathrm{Na}-\mathrm{K}-\mathrm{Cl}$ co-transporter $(\mathrm{NKCC} 1)$ in the gerbil inner ear. J Histochem Cytochem 45:773-778.

de Kok YJ, van der Maarel SM, Bitner-Glindzicz M, Huber I, et al. (1995) Association between $\mathrm{X}$-linked mixed deafness and mutations in the POU domain gene POU3F4. Science 267:685-688.

Delpire E, Lu J, England R, Dull C, et al. (1999) Deafness and imbalance associated with inactivation of the secretory $\mathrm{Na}-\mathrm{K}-2 \mathrm{Cl}$ co-transporter. Nat Genet 22:192-195.

Deol MS (1964) The abnormalities of the inner ear in kreisler mice. J Embryol Exp Morphol 12:475-490.

Deol M (1966) Influence of the neural tube on the differentiation of the inner ear in the mammalian embryo. Nature 209:219-220. 
Deol MS (1983) Development of auditory and vestibular systems in mutant mice. In: Romand R (ed) Development of Auditory and Vestibular Systems. New York: Academic Press, pp. 309-333.

Depew MJ, Liu JK, Long JE, Presley R, et al. (1999) Dlx5 regulates regional development of the branchial arches and sensory capsules. Development 126: $3831-3846$.

Dewulf N, Verschueren K, Lonnoy O, Moren A, et al. (1995) Distinct spatial and temporal expression patterns of two type I receptors for bone morphogenetic proteins during mouse embryogenesis. Endocrinology 136:2652-2663.

Dixon MJ, Gazzard J, Chaudhry SS, Sampson N, et al. (1999) Mutation of the $\mathrm{Na}-\mathrm{K}-\mathrm{Cl}$ co-transporter gene Slc12a2 results in deafness in mice. Hum Mol Genet 8:1579-1584.

Dohlman G (1961) Excretion and absorption of endolymph in the vestibular apparatus. In: de Reuck AVS, Knight H (eds) Ciba Foundation Symposium in Motatic, Kinesthetic and Vestibular Mechanisms. London: Churchill, pp. 138-143.

Eddison M, Le Roux I, Lewis J (2000) Notch signaling in the development of the inner ear: lessons from Drosophila. Proc Natl Acad Sci USA 97:11692-11699.

Epstein DJ, Vekemans M, Gros P (1991) Splotch (Sp2H), a mutation affecting development of the mouse neural tube, shows a deletion within the paired homeodomain of Pax-3. Cell 67:767-774.

Everett LA, Glaser B, Beck JC, Idol JR, et al. (1997) Pendred syndrome is caused by mutations in a putative sulphate transporter gene (PDS). Nat Genet 17: 411422.

Everett LA, Morsli H, Wu DK, Green ED (1999) Expression pattern of the mouse ortholog of the Pendred's syndrome gene (Pds) suggests a key role for pendrin in the inner ear. Proc Natl Acad Sci USA 96:9727-9732.

Everett LA, Belyantseva IA, Noben-Trauth K, Cantos R, et al. (2001) Targeted disruption of mouse Pds provides key insight about the inner-ear defects encountered in Pendred syndrome. Hum Mol Genet 10:153-161.

Evrard YA, Lun Y, Aulehla A, Gan L, et al. (1998) Lunatic fringe is an essential mediator of somite segmentation and patterning. Nature 394:377-381.

Failli V, Bachy I, Retaux S (2002) Expression of the LIM-homeodomain gene Lmx1a (dreher) during development of the mouse nervous system. Mech Dev 118: 225-228.

Fekete DM (1999) Development of the vertebrate ear: insights from knockouts and mutants. Trends Neurosci 22:263-269.

Fekete DM, Wu DK (2002) Revisiting cell fate specification in the inner ear. Curr Opin Neurobiol 12:35-42.

Fekete DM, Homburger SA, Waring MT, Riedl AE, et al. (1997) Involvement of programmed cell death in morphogenesis of the vertebrate inner ear. Development 124:2451-2461.

Flanagan JG, Vanderhaeghen P (1998) The ephrins and Eph receptors in neural development. Annu Rev Neurosci 21:309-345.

Frenz DA, Galinovic-Schwartz V, Liu W, Flanders KC, et al. (1992) Transforming growth factor beta 1 is an epithelial-derived signal peptide that influences otic capsule formation. Dev Biol 153:324-336.

Frenz DA, Liu W, Williams JD, Hatcher V, et al. (1994) Induction of chondrogenesis: requirement for synergistic interaction of basic fibroblast growth factor and transforming growth factor-beta. Development 120:415-424. 
Frenz DA, Liu W, Capparelli M (1996) Role of BMP-2a in otic capsule chondrogenesis. Ann NY Acad Sci 785:256-258.

Frisen J, Holmberg J, Barbacid M (1999) Ephrins and their Eph receptors: multitalented directors of embryonic development. EMBO J 18:5159-5165.

Fritzsch B, Silos-Santiago I, Smeyne R, Fagan M, et al. (1995) Reduction and loss of inner ear innervation in trkB and trkC receptor knockout mice: a whole mount DiI and scanning electron microscopic analysis. Aud Neurosci 1:401-417.

Fritzsch B, Silos-Santiago I, Bianchi LM, Farinas I (1997) Effects of neurotrophin and neurotrophin receptor disruption on the afferent inner ear innervation. Semin Cell Dev Biol 8:277-284.

Fritzsch B, Barald KF, Lomax MI (1998) Early embryology of the vertebrate ear. In: Rubel EW, Popper AN, Fay RR (eds) Development of the Auditory System. Springer Handbook of Auditory Research, Volume 9. New York: Springer, pp. 80-145.

Fritzsch B, Pirvola U, Ylikoski J (1999) Making and breaking the innervation of the ear: neurotrophic support during ear development and its clinical implications. Cell Tissue Res 295:369-382.

Fritzsch B, Beisel KW, Bermingham NA (2000) Developmental evolutionary biology of the vertebrate ear: conserving mechanoelectric transduction and developmental pathways in diverging morphologies. Neuroreport 11:R35-44.

Fritzsch B, Signore M, Simeone A (2001) Otx1 null mutants show partial segregation of sensory epithelial comparable to lamprey ears. Dev Genes Evol 211: 388-396.

Gavalas A, Studer M, Lumsden A, Rijli FM, et al. (1998) Hoxa1 and Hoxb1 synergize in patterning the hindbrain, cranial nerves and second pharyngeal arch. Development 125:1123-1136.

Gerlach LM, Hutson MR, Germiller JA, Nguyen-Luu D, et al. (2000) Addition of the BMP4 antagonist, noggin, disrupts avian inner ear development. Development 127:45-54.

Giraldez F (1998) Regionalized organizing activity of the neural tube revealed by the regulation of $\operatorname{lmx} 1$ in the otic vesicle. Dev Biol 203:189-200.

Goto S, Oshima T, Ikeda K, Ueda N, et al. (1997) Expression and localization of the $\mathrm{Na}-\mathrm{K}-2 \mathrm{Cl}$ cotransporter in the rat cochlea. Brain Res 765:324-326.

Goulding M, Sterrer S, Fleming J, Balling R, et al. (1993) Analysis of the Pax-3 gene in the mouse mutant splotch. Genomics 17:355-363.

Goulding MD, Chalepakis G, Deutsch U, Erselius JR, et al. (1991) Pax-3, a novel murine DNA binding protein expressed during early neurogenesis. EMBO J 10:1135-1147.

Haddon C, Jiang YJ, Smithers L, Lewis J (1998) Delta-Notch signalling and the patterning of sensory cell differentiation in the zebrafish ear: evidence from the mind bomb mutant. Development 125:4637-4644.

Hadrys T, Braun T, Rinkwitz-Brandt S, Arnold HH, et al. (1998) Nkx5-1 controls semicircular canal formation in the mouse inner ear. Development 125:33-39.

Hallbook F, Ibanez CF, Ebendal T, Persson H (1993) Cellular localization of brainderived neurotrophic factor and neurotrophin-3 mRNA expression in the early chicken embryo. Eur J Neurosci 5:1-14.

Hemmati-Brivanlou A, Thomsen GH (1995) Ventral mesodermal patterning in Xenopus embryos: expression patterns and activities of BMP-2 and BMP-4. Dev Genet 17:78-89. 
Hicks C, Johnston SH, diSibio G, Collazo A, et al. (2000) Fringe differentially modulates Jagged1 and Delta1 signalling through Notch1 and Notch2. Nat Cell Biol 2:515-520.

Hirth F, Therianos S, Loop T, Gehring WJ, et al. (1995) Developmental defects in brain segmentation caused by mutations of the homeobox genes orthodenticle and empty spiracles in Drosophila. Neuron 15:769-778.

Hogan BL (1996) Bone morphogenetic proteins: multifunctional regulators of vertebrate development. Genes Dev 10:1580-1594.

Huang EJ, Liu W, Fritzsch B, Bianchi LM, et al. (2001) Brn-3a is a transcriptional regulator of soma size, target field innervation, and axon pathfinding of Inner ear sensory neurons. Development 126:2869-2882.

Hui CC, Slusarski D, Platt KA, Holmgren R, et al. (1994) Expression of three mouse homologs of the Drosophila segment polarity gene cubitus interruptus, Gli, Gli2 and Gli-3, in ectoderm- and mesoderm-derived tissues suggests multiple roles during postimplantation development. Dev Biol 162:402-413.

Johnsen T, Jorgensen MB, Johnsen S (1986) Mondini cochlea in Pendred's syndrome. A histological study. Acta Otolaryngol 102:239-247.

Johnson DR (1967) Extra-toes: a new mutant gene causing multiple abnormalities in the mouse. J Embryol Exp Morphol 17:543-581.

Johnson KR, Cook SA, Erway LC, Matthews AN, et al. (1999) Inner ear and kidney anomalies caused by IAP insertion in an intron of the Eya1 gene in a mouse model of BOR syndrome. Hum Mol Genet 8:645-653.

Ju BG, Jeong S, Bae E, Hyun S, et al. (2000) Fringe forms a complex with Notch. Nature 405:191-195.

Kalatzis V, Sahly I, El-Amraoui A, Petit C (1998) Eya1 expression in the developing ear and kidney: towards the understanding of the pathogenesis of BranchioOto-Renal (BOR) syndrome. Dev Dyn 213:486-499.

Karis A, Pata I, van Doorninck JH, Grosveld F, et al. (2001) Transcription factor GATA-3 alters pathway selection of olivocochlear neurons and affects morphogenesis of the ear. J Comp Neurol 429:615-630.

Kharkovets T, Hardelin JP, Safieddine S, Schweizer M, et al. (2000) KCNQ4, a K channel mutated in a form of dominant deafness, is expressed in the inner ear and the central auditory pathway. Proc Natl Acad Sci USA 97:4333-4338.

Kiernan AE, Nunes F, Wu DK, Fekete DM (1997) The expression domain of two related homeobox genes defines a compartment in the chicken inner ear that may be involved in semicircular canal formation. Dev Biol 191:215-229.

Kiernan AE, Ahituv N, Fuchs H, Balling R, et al. (2001) The Notch ligand Jagged1 is required for inner ear sensory development. Proc Natl Acad Sci USA 98:3873-3878.

Kiernan AE, Steel KP, Fekete DM (2002) Development of the mouse inner ear. In: Rossant JT, Tam PPL (eds) Mouse Development: Patterning, Morphogenesis, and Organogenesis. Orlando, FL: Academic Press, pp. 539-566.

Kikuchi T, Kimura RS, Paul DL, Adams JC (1995) Gap junctions in the rat cochlea: immunohistochemical and ultrastructural analysis. Anat Embryol (Berl) 191: 101-118.

Kil SH, Collazo A (2002) A review of inner ear fate maps and cell lineage studies. J Neurobiol 53:129-142.

Kim WY, Fritzsch B, Serls A, Bakel LA, et al. (2001) NeuroD-null mice are deaf due to a severe loss of the inner ear sensory neurons during development. Development 128:417-426. 
Kubisch C, Schroeder BC, Friedrich T, Lutjohann B, et al. (1999) KCNQ4, a novel potassium channel expressed in sensory outer hair cells, is mutated in dominant deafness. Cell 96:437-446.

Ladher RK, Anakwe KU, Gurney AL, Schoenwolf GC, et al. (2000) Identification of synergistic signals initiating inner ear development. Science 290:1965-1967.

Landolt JP, Correia MJ, Young ER, Cardin RP, et al. (1975) A scanning electron microscopic study of the morphology and geometry of neural surfaces and structures associated with the vestibular apparatus of the pigeon. J Comp Neurol 159:257-287.

Lanford PJ, Lan Y, Jiang R, Lindsell C, et al. (1999) Notch signalling pathway mediates hair cell development in mammalian cochlea. Nat Genet 21:289-292.

Laufer E, Dahn R, Orozco OE, Yeo CY, et al. (1997) Expression of Radical fringe in limb-bud ectoderm regulates apical ectodermal ridge formation [see comments] Nature 386:366-373. [published erratum appears in Nature 388:400 (1997)].

Lee JE, Hollenberg SM, Snider L, Turner DL, et al. (1995) Conversion of Xenopus ectoderm into neurons by NeuroD, a basic helix- loop-helix protein. Science 268:836-844.

Lee MP, Ravenel JD, Hu RJ, Lustig LR, et al. (2000) Targeted disruption of the Kvlqt1 gene causes deafness and gastric hyperplasia in mice. J Clin Invest 106:1447-1455.

Leger S, Brand M (2002) Fgf8 and Fgf3 are required for zebrafish ear placode induction, maintenance and inner ear patterning. Mech Dev 119:91.

Leimeister C, Externbrink A, Klamt B, Gessler M (1999) Hey genes: a novel subfamily of hairy- and Enhancer of split related genes specifically expressed during mouse embryogenesis. Mech Dev 85:173-177.

Letts VA, Valenzuela A, Dunbar C, Zheng QY, et al. (2000) A new spontaneous mouse mutation in the Kcnel gene. Mamm Genome 11:831-835.

Lewis AK, Frantz GD, Carpenter DA, de Sauvage FJ, et al. (1998) Distinct expression patterns of notch family receptors and ligands during development of the mammalian inner ear. Mech Dev 78:159-163.

Li XC, Everett LA, Lalwani AK, Desmukh D, et al. (1998) A mutation in PDS causes non-syndromic recessive deafness. Nat Genet 18:215-217.

Liu M, Pereira FA, Price SD, Chu M, et al. (2000) Essential role of BETA2/NeuroD1 in development of the vestibular and auditory systems. Genes Dev 14:28392854.

Liu W, Li G, Chien JS, Raft S, et al. (2002) Sonic hedgehog regulates otic capsule chondrogenesis and inner ear development in the mouse embryo. Dev Biol 248:240-250.

Livesey FJ (1999) Netrins and netrin receptors. Cell Mol Life Sci 56:62-68.

Ma Q, Chen Z, Barrantes I, de la Pompa JL, et al. (1998) Neurogenin 1 is essential for the determination of neuronal precursors for proximal cranial sensory ganglia. Neuron 20:469-482.

Ma Q, Anderson DJ, Fritzsch B (2000) Neurogenin 1 null mutant ears develop fewer, morphologically normal hair cells in smaller sensory epithelia devoid of innervation. J Assoc Res Otolaryngol 1:129-143.

Maconochie M, Nonchev S, Morrison A, Krumlauf R (1996) Paralogous Hox genes: function and regulation. Annu Rev Genet 30:529-556.

Malicki J, Schier AF, Solnica-Krezel L, Stemple DL, et al. (1996) Mutations affecting development of the zebrafish ear. Development 123:275-283. 
Manfre L, Genuardi P, Tortorici M, Lagalla R (1997) Absence of the common crus in Goldenhar syndrome. Am J Neuroradiol 18:773-775.

Mansour SL (1994) Targeted disruption of int-2 (fgf-3) causes developmental defects in the tail and inner ear. Mol Reprod Dev 39:62-68.

Mansour SL, Goddard JM, Capecchi MR (1993) Mice homozygous for a targeted disruption of the proto-oncogene int-2 have developmental defects in the tail and inner ear. Development 117:13-28.

Manzanares M, Trainor PA, Ariza-McNaughton L, Nonchev S, et al. (2000) Dorsal patterning defects in the hindbrain, roof plate and skeleton in the dreher $(\operatorname{dr}(\mathrm{J}))$ mouse mutant. Mech Dev 94:147-156.

Mark M, Lufkin T, Vonesch JL, Ruberte E, et al. (1993) Two rhombomeres are altered in Hoxa-1 mutant mice. Development 119:319-338.

Maroon H, Walshe J, Mahmood R, Kiefer P, et al. (2002) Fgf3 and Fgf8 are required together for formation of the otic placode and vesicle. Development 129: 2099-2108.

Maruyama K, Tsukada T, Ohkura N, Bandoh S, et al. (1998) The NGFI-B subfamily of the nuclear receptor superfamily (review). Int J Oncol 12:1237-1243.

McKay IJ, Lewis J, Lumsden A (1996) The role of FGF-3 in early inner ear development: an analysis in normal and kreisler mutant mice. Dev Biol 174:370-378.

Merlo GR, Paleari L, Mantero S, Zerega B, et al. (2002) The Dlx5 homeobox gene is essential for vestibular morphogenesis in the mouse embryo through a BMP4mediated pathway. Dev Biol 248:157-169.

Millonig JH, Millen KJ, Hatten ME (2000) The mouse Dreher gene Lmx1a controls formation of the roof plate in the vertebrate CNS. Nature 403:764-769.

Minowa O, Ikeda K, Sugitani Y, Oshima T, et al. (1999) Altered cochlear fibrocytes in a mouse model of DFN3 nonsyndromic deafness [see comments]. Science 285:1408-1411.

Mizuta K, Adachi M, Iwasa KH (1997) Ultrastructural localization of the Na-K-Cl cotransporter in the lateral wall of the rabbit cochlear duct. Hear Res 106: $154-162$.

Morrison A, Hodgetts C, Gossler A, Hrabe de Angelis M, et al. (1999) Expression of Delta1 and Serrate1 (Jagged1) in the mouse inner ear. Mech Dev 84:169-172.

Morsli H, Choo D, Ryan A, Johnson R, et al. (1998) Development of the mouse inner ear and origin of its sensory organs. J Neurosci 18:3327-3335.

Morsli H, Tuorto F, Choo D, Postiglione MP, et al. (1999) Otx1 and Otx2 activities are required for the normal development of the mouse inner ear. Development 126:2335-2343.

Mowbray C, Hammerschmidt M, Whitfield TT (2001) Expression of BMP signaling pathway member in the developing zebrafish inner ear and lateral line. MOD 108:179-184.

Myat A, Henrique D, Ish-Horowicz D, Lewis J (1996) A chick homologue of Serrate and its relationship with Notch and Delta homologues during central neurogenesis. Dev Biol 174:233-247.

Nardelli J, Thiesson D, Fujiwara Y, Tsai FY, et al. (1999) Expression and genetic interaction of transcription factors GATA-2 and GATA-3 during development of the mouse central nervous system. Dev Biol 210:305-321.

Neyroud N, Tesson F, Denjoy I, Leibovici M, et al. (1997) A novel mutation in the potassium channel gene KVLQT1 causes the Jervell and Lange-Nielsen cardioauditory syndrome. Nat Genet 15:186-189. 
Noramly S, Grainger RM (2002) Determination of the embryonic inner ear. J Neurobiol 53:100-128.

O'Hara E, Cohen B, Cohen SM, McGinnis W (1993) Distal-less is a downstream gene of Deformed required for ventral maxillary identity. Development 117 : 847-856.

Panin VM, Papayannopoulos V, Wilson R, Irvine KD (1997) Fringe modulates Notch-ligand interactions. Nature 387:908-912.

Papayannopoulos V, Tomlinson A, Panin VM, Rauskolb C, et al. (1998) Dorsal-ventral signaling in the Drosophila eye. Science 281:2031-2034.

Patel S, Latterich M (1998) The AAA team: related ATPases with diverse functions. Trends Cell Biol 8:65-71.

Pauley S, Wright T, Pirvola U, Ornitz DM, Beisel KW, et al. (2003) Expression and function of FGF-10 in mammalian inner ear development. Dev Dynamics 227:203-215.

Phillips BT, Bolding K, Riley BB (2001) Zebrafish Fgf3 and Fgf8 encode redundant functions required for otic placode induction. Dev Biol 235:351-365.

Phippard D, Heydemann A, Lechner M, Lu L, et al. (1998) Changes in the subcellular localization of the Brn4 gene product precede mesenchymal remodeling of the otic capsule. Hear Res 120:77-85.

Phippard D, Lu L, Lee D, Saunders JC, et al. (1999) Targeted mutagenesis of the POU-domain gene Brn4/Pou3f4 causes developmental defects in the inner ear. J Neurosci 19:5980-5989.

Phippard D, Boyd Y, Reed V, Fisher G, et al. (2000) The sex-linked fidget mutation abolishes Brn4/Pou3f4 gene expression in the embryonic inner ear. Hum Mol Genet 9:79-85.

Pignoni F, Hu B, Zavitz KH, Xiao J, et al. (1997) The eye-specification proteins So and Eya form a complex and regulate multiple steps in Drosophila eye development. Cell 91:881-891.

Pirvola U, Spencer-Dene B, Xing-Qun L, Kettunen P, et al. (2000) Fgf/Fgfr-2 (IIIb) signaling is essential for inner ear morphogenesis. J Neurosci 20:6125-6134.

Pissarra L, Henrique D, Duarte A (2000) Expression of hes6, a new member of the Hairy/Enhancer-of-split family, in mouse development. Mech Dev 95:275-278.

Ponnio T, Burton Q, Pereira FA, Wu DK, et al. (2002) The nuclear receptor Nor-1 is essential for proliferation of the semicircular canals of the mouse inner ear. Mol Cell Biol 22:935-945.

Riccomagno MM, Martinu L, Mulheisen M, Wu DK, et al. (2002) Specification of the mammalian cochlea is dependent to Sonic hedgehog. Genes Dev 16:2365-2378.

Rijli FM, Mark M, Lakkaraju S, Dierich A, et al. (1993) A homeotic transformation is generated in the rostral branchial region of the head by disruption of Hoxa-2, which acts as a selector gene. Cell 75:1333-1349.

Rinkwitz S, Bober E, Baker R (2001) Development of the vertebrate inner ear. Ann NY Acad Sci 942:1-14.

Rinkwitz-Brandt S, Justus M, Oldenettel I, Arnold HH, et al. (1995) Distinct temporal expression of mouse Nkx-5.1 and Nkx-5.2 homeobox genes during brain and ear development. Mech Dev 52:371-381.

Rinkwitz-Brandt S, Arnold HH, Bober E (1996) Regionalized expression of Nkx51, Nkx5-2, Pax2 and sek genes during mouse inner ear development. Hear Res 99:129-138. 
Rivolta MN, Holley MC (1998) GATA3 is downregulated during hair cell differentiation in the mouse cochlea. J Neurocytol 27:637-647.

Robinson GW, Mahon KA (1994) Differential and overlapping expression domains of Dlx-2 and Dlx-3 suggest distinct roles for Distal-less homeobox genes in craniofacial development. Mech Dev 48:199-215.

Royet J, Finkelstein R (1995) Pattern formation in Drosophila head development: the role of the orthodenticle homeobox gene. Development 121:3561-3572.

Sakagami M, Fukazawa K, Matsunaga T, Fujita H, et al. (1991) Cellular localization of rat Isk protein in the stria vascularis by immunohistochemical observation. Hear Res 56:168-172.

Salminen M, Meyer BI, Bober E, Gruss P (2000) Netrin 1 is required for semicircular canal formation in the mouse inner ear. Development 127:13-22.

Satokata I, Maas R (1994) Msx1 deficient mice exhibit cleft palate and abnormalities of craniofacial and tooth development. Nat Genet 6:348-356.

Schimmang T, Lemaistre M, Vortkamp A, Ruther U (1992) Expression of the zinc finger gene Gli3 is affected in the morphogenetic mouse mutant extra-toes (Xt). Development 116:799-804.

Schimmang T, Minichiello L, Vazquez E, San Jose I, et al. (1995) Developing inner ear sensory neurons require TrkB and TrkC receptors for innervation of their peripheral targets. Development 121:3381-3391.

Schulze-Bahr E, Wang Q, Wedeking H, Haverkamp W, et al. (1997) KCNE1 mutations cause Jervell and Lange-Nielsen syndrome. Nat Genet 17:267-268.

Scott DA, Wang R, Kreman TM, Sheffield VC, et al. (1999) The Pendred syndrome gene encodes a chloride-iodide transport protein. Nat Genet 21:440-443.

Shailam R, Lanford PJ, Dolinsky CM, Norton CR, et al. (1999) Expression of proneural and neurogenic genes in the embryonic mammalian vestibular system. J Neurocytol 28:809-819.

Silos-Santiago I, Fagan AM, Garber M, Fritzsch B, et al. (1997) Severe sensory deficits but normal CNS development in newborn mice lacking TrkB and TrkC tyrosine protein kinase receptors. Eur J Neurosci 9:2045-2056.

Simeone A, Acampora D, Pannese M, D'Esposito M, et al. (1994) Cloning and characterization of two members of the vertebrate Dlx gene family. Proc Natl Acad Sci USA 91:2250-2254.

Simon MC (1995) Gotta have GATA. Nat Genet 11:9-11.

Spicer SS, Schulte BA (1998) Evidence for a medial $\mathrm{K}^{+}$recycling pathway from inner hair cells. Hear Res 118:1-12.

Steel KP, Kros CJ (2001) A genetic approach to understanding auditory function. Nat Genet 27:143-149.

Steel KP, Erven A, Kiernan AE (2002) Mice as models for human hereditary deafness. In: Keats BJB, Popper AN, Fay Rr (eds) Genetics and Auditory Disorders. Springer Handbook of Auditory Research, Volume 14. New York: SpringerVerlag, pp. 247-296.

ten Berge D, Brouwer A, Korving J, Martin JF, et al. (1998) Prx1 and Prx2 in skeletogenesis: roles in the craniofacial region, inner ear and limbs. Development 125:3831-3842.

Teng X, Ahn K, Bove M, Frenz D, et al. (2000) Malformations of the lateral semicircular canal occur in heterozygous Bmp4 mice. Assoc Res Otolaryngol Abstr 181:51. 
Torres M, Giraldez F (1998) The development of the vertebrate inner ear. Mech Dev 71:5-21.

Truslove GM (1956) The anatomy and development of the Fidget mouse. J Genet 54:64-86.

Tsai H, Hardisty RE, Rhodes C, Kiernan AE, et al. (2001) The mouse slalom mutant demonstrates a role for Jagged1 in neuroepithelial patterning in the organ of Corti. Hum Mol Genet 10:507-512.

Van de Water TR, Li CW, Ruben RJ, Shea CA (1980) Ontogenic aspects of mammalian inner ear development. Birth Defects 16:5-45.

Vendrell V, Carnicero E, Giraldez F, Alonso MT, et al. (2000) Induction of inner ear fate by FGF3. Development 127:2011-2019.

Verpy E, Leibovici M, Petit c (1999) Characterization of Otoconin-95, the major protein of murine otoconia, provides insights into the formation of these inner ear biominerals. Proc Natl Acad Sci USA 96:529-534.

Vetter DE, Mann JR, Wangemann P, Liu J, et al. (1996) Inner ear defects induced by null mutation of the isk gene. Neuron 17:1251-1264.

Wang W, Van de Water T, Lufkin T (1998) Inner ear and maternal reproductive defects in mice lacking the Hmx3 homeobox gene. Development 125:621634.

Wang W, Chan EK, Baron S, Van de Water T, et al. (2001) Hmx2 homeobox gene control of murine vestibular morphogenesis. Development 128:5017-5029.

Wangemann P, Liu J, Marcus DC (1995) Ion transport mechanisms responsible for $\mathrm{K}^{+}$secretion and the transepithelial voltage across marginal cells of stria vascularis in vitro. Hear Res 84:19-29.

Wersäll J, Bagger-Sjöbäck D (1974) Morphology of the vestibular sense organ. In: Autrum H, Jung R, Loenstein WR, Mackay DM (eds) Handbook of Sensory Physiology: Vestibular System, Part I. New York: Springer-Verlag, pp. 124-170.

Whitfield TT (2002) Zebrafish as a model for hearing and deafness. J Neurobiol 53:157-171.

Whitfield TT, Granato M, van Eeden FJ, Schach U, et al. (1996) Mutations affecting development of the zebrafish inner ear and lateral line. Development 123:241-254.

Wilcox ER, Burton QL, Naz S, Riazuddin S, et al. (2001) Mutations in the gene encoding tight junction claudin-14 cause autosomal recessive deafness DFNB29. Cell 104:165-172.

Wilkinson DG, Bhatt S, McMahon AP (1989) Expression pattern of the FGF-related proto-oncogene int-2 suggests multiple roles in fetal development. Development 105:131-136.

Winnier G, Blessing M, Labosky PA, Hogan BLM (1995) Bone morphogenetic protein-4 is required for mesoderm formation and patterning in the mouse. Genes Dev 9:2105-2116.

Wright TJ, Mansour SL (2003) Fgf3 and Fgf10 are required for mouse otic placode induction. Development, 130:3379-3390.

Wu DK, Oh SH (1996) Sensory organ generation in the chick inner ear. J Neurosci 16:6454-6462.

Wu DK, Choo DI (2003) Development of the ear. In: Snow JB Jr (eds) Ballengers, Manual of Otorhinolaryngology Head and Neck Surgery. Hamilton, Ontario, Canada: BC Decker, Inc., pp. 25-37. 
Wu DK, Nunes FD, Choo D (1998) Axial specification for sensory organs versus non-sensory structures of the chicken inner ear. Development 125:11-20.

Xu PX, Woo I, Her H, Beier DR, et al. (1997) Mouse Eya homologues of the Drosophila eyes absent gene require Pax6 for expression in lens and nasal placode. Development 124:219-231.

Xu PX, Adams J, Peters H, Brown MC, et al. (1999) Eya1-deficient mice lack ears and kidneys and show abnormal apoptosis of organ primordia. Nat Genet 23: 113-117.

Zhang N, Gridley T (1998) Defects in somite formation in Lunatic fringe-deficient mice. Nature 394:374-377.

Zhang N, Martin GV, Kelley MW, Gridley T (2000) A mutation in the Lunatic fringe gene suppresses the effects of a Jagged 2 mutation on inner hair cell development in the cochlea. Curr Biol 10:659-662.

Zheng JL, Gao WQ (2000) Overexpression of Math1 induces robust production of extra hair cells in postnatal rat inner ears. Nat Neurosci 3:580-586.

Zheng JL, Shou J, Guillemot F, Kageyama R, et al. (2000) Hes1 is a negative regulator of inner ear hair cell differentiation. Development 127:4551-4560.

Zine A, Van de Water TR, de Ribaupierre F (2000) Notch signaling regulates the pattern of auditory hair cell differentiation in mammals. Development 127: 3373-3383. 